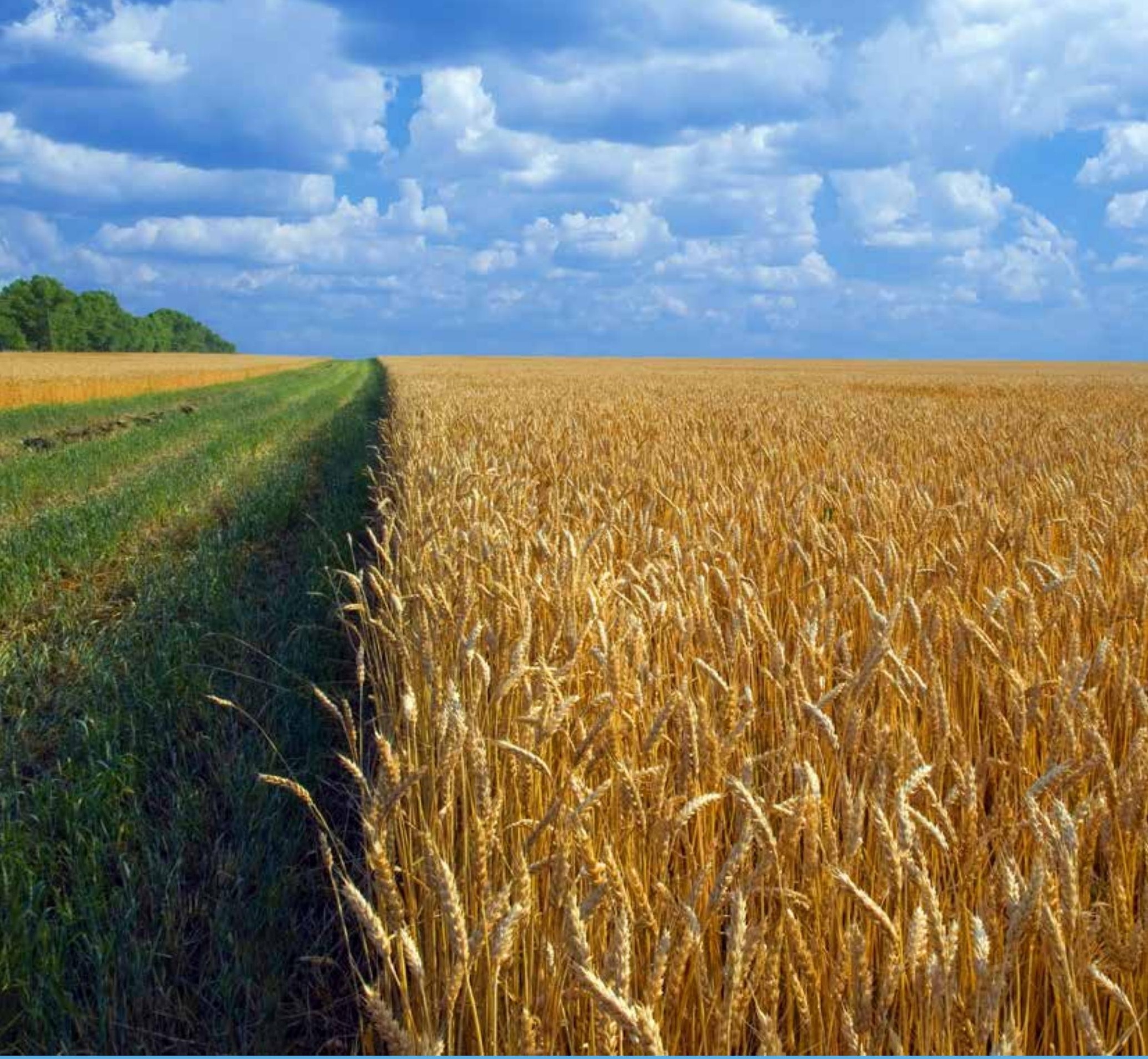

\title{
Voorstellen stabilisering pachtnormen onder de loep
}

Huib Silvis en Martien Voskuilen

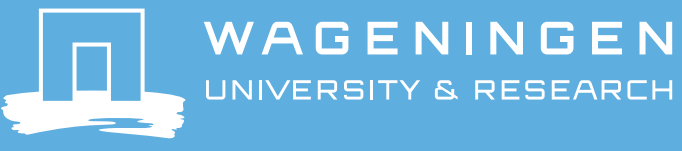





\section{Voorstellen stabilisering pachtnormen onder de loep}

Huib Silvis en Martien Voskuilen

Dit onderzoek is uitgevoerd door Wageningen Economic Research in opdracht van en gefinancierd door het ministerie van Economische Zaken, in het kader van het Beleidsondersteunend onderzoeksthema 'Agroeconomie, markt en handel' (projectnummer BO 20-019-047).

Wageningen Economic Research

Wageningen, november 2016

NOTA

2016-115 
Silvis, H.J. en M.J. Voskuilen, 2016. Voorstellen stabilisering pachtnormen onder de loep. Wageningen, Wageningen Economic Research, Nota 2016-115. 30 blz.; 18 fig.; 12 tab.; 6 ref.

De pachtnormen verschillen van jaar op jaar en tussen de pachtprijsgebieden. Dat komt omdat ze gebaseerd zijn op de grondbeloning in de landbouw, die van jaar op jaar sterk kan variëren. In het overleg van Spelderholt zijn enkele voorstellen gedaan om de jaarlijkse wisselingen van de pachtnormen met indexering te verminderen. In opdracht van het ministerie van Economische Zaken heeft Wageningen Economic Research deze methoden geanalyseerd en ook enkele andere opties verkend.

Trefwoorden: pachtprijs, pachtnormen, pachtprijsgebieden, grondbeloning, indexering, grondprijs, consumentenprijsindex, veranderpercentages

Dit rapport is gratis te downloaden op http://dx.doi.org/10.18174/398011 of op www.wur.nl/economic-research (onder Wageningen Economic Research publicaties).

(C) 2016 Wageningen Economic Research

Postbus 29703, 2502 LS Den Haag, T 07033583 30, E communications.ssg@wur.nl, www.wur.nl/economic-research. Wageningen Economic Research is onderdeel van Wageningen University \& Research.

\section{(cc) BY-NC}

Wageningen Economic Research hanteert voor haar rapporten een Creative Commons Naamsvermelding 3.0 Nederland licentie.

(C) Wageningen Economic Research, onderdeel van Stichting Wageningen Research, 2016 De gebruiker mag het werk kopiëren, verspreiden en doorgeven en afgeleide werken maken. Materiaal van derden waarvan in het werk gebruik is gemaakt en waarop intellectuele eigendomsrechten berusten, mogen niet zonder voorafgaande toestemming van derden gebruikt worden. De gebruiker dient bij het werk de door de maker of de licentiegever aangegeven naam te vermelden, maar niet zodanig dat de indruk gewekt wordt dat zij daarmee instemmen met het werk van de gebruiker of het gebruik van het werk. De gebruiker mag het werk niet voor commerciële doeleinden gebruiken.

Wageningen Economic Research aanvaardt geen aansprakelijkheid voor eventuele schade voortvloeiend uit het gebruik van de resultaten van dit onderzoek of de toepassing van de adviezen.

Wageningen Economic Research is ISO 9001:2008 gecertificeerd.

Wageningen Economic Research Nota 2016-115 | Projectcode 2282200219

Foto omslag: Shutterstock 


\section{Inhoud}

Woord vooraf $\quad 5$

$\begin{array}{ll}\text { Samenvatting } & 6\end{array}$

$\begin{array}{lll}\text { S.1 Belangrijkste uitkomsten } & 6\end{array}$

S.2 Vraagstelling en methode $\quad 6$

$\begin{array}{lll}1 & \text { Inleiding } & 7\end{array}$

$\begin{array}{lll}1.1 & \text { Aanleiding } & 7\end{array}$

$\begin{array}{lll}1.2 & \text { Onderzoeksvragen } & 7\end{array}$

$\begin{array}{lll}1.3 \text { Aanpak } & 7\end{array}$

$\begin{array}{llr}2 & \text { Fluctuaties in pachtnormen en pachtprijzen } & 8\end{array}$

$\begin{array}{lll}2.1 & \text { Inleiding } & 8\end{array}$

2.2 Pachtnormen $\quad 8$

2.3 Betaalde pachtprijzen 9

2.4 Conclusie 11

$3 \quad$ Indexering met agrarische grondprijs $\quad 12$

3.1 Inleiding $\quad 12$

3.2 Uitwerking systematiek $\quad 12$

$\begin{array}{lll}3.3 & \text { Toepassing systematiek } & 13\end{array}$

$\begin{array}{lll}3.4 & \text { Conclusie } & 15\end{array}$

$\begin{array}{llr}4 & \text { Indexering via consumentenprijsindex } & 16\end{array}$

$\begin{array}{lll}4.1 & \text { Inleiding } & 16\end{array}$

$\begin{array}{lll}4.2 & \text { Uitwerking systematiek } & 16\end{array}$

\begin{tabular}{ll}
4.3 & Toepassing systematiek \\
\hline 4.4 & 17
\end{tabular}

$\begin{array}{lll}4.4 & \text { Conclusie } & 17\end{array}$

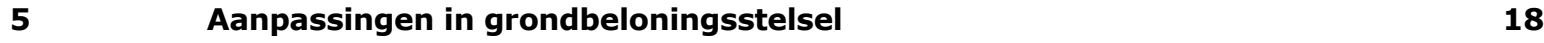

5.1 Inleiding $\quad 18$

$\begin{array}{lll}5.2 & \text { Extra middeling } & 18\end{array}$

5.3 Andere mogelijkheden $\quad 19$

$\begin{array}{ll}\text { Literatuur en websites } & \mathbf{2 0}\end{array}$

$\begin{array}{lll}\text { Bijlage } 1 \text { Grondbeloning } & 21\end{array}$

Bijlage 2 Pachtnormen $\quad 22$

$\begin{array}{lll}\text { Bijlage } 3 & \text { Betaalde pachtprijzen } & 23\end{array}$

$\begin{array}{lll}\text { Bijlage } 4 & \begin{array}{l}\text { Grondbeloning, pachtnormen en betaalde pachtprijzen } \\ \text { (euro/ha) per pachtprijsgebied }\end{array}\end{array}$ 



\section{Woord vooraf}

Dit rapport is opgesteld in opdracht van het ministerie van Economische Zaken (EZ). Het is een aanvulling op de jaarlijkse berekening van de pachtnormen, de hoogst toelaatbare pachtprijzen per pachtprijsgebied (LEI Nota 2016-053). De pachtnormen gelden voor reguliere pacht en voor geliberaliseerde pacht langer dan zes jaar. Ze verschillen van jaar op jaar en tussen de pachtprijsgebieden. Ondanks de stabiliserende elementen in de berekeningswijze, vertonen de uitkomsten van jaar op jaar flinke schommelingen.

Dit rapport laat zien dat de schommelingen voortvloeien uit de wettelijk vastgelegde afspraak om de normen te baseren op de bedrijfsresultaten in de landbouw. Bij het overleg van Spelderholt is voorgesteld om de jaarlijkse wisselingen in de pachtnormen te verminderen met behulp van indexering. De indexeringsvoorstellen koppelen de normen aan andere indicatoren zoals de agrarische grondprijs en de koopkracht van de euro. In dit rapport worden ook andere opties verkend.

Namens de opdrachtgever is het onderzoek begeleid door Liesbeth Kap en Henk Riphagen van de directie Europees Landbouw- en Visserijbeleid en Voedselzekerheid van het ministerie van Economische Zaken.

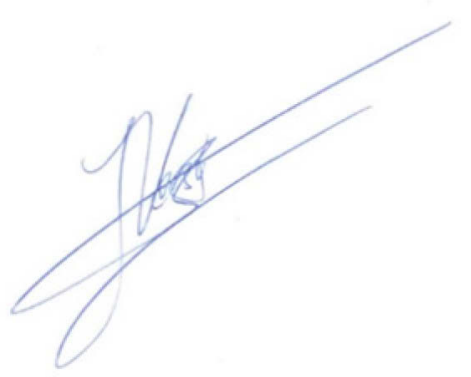

Prof. dr. ir. Jack (J.G.A.J.) van der Vorst Algemeen Directeur Social Sciences Group Wageningen University \& Research 


\title{
Samenvatting
}

\section{S.1 Belangrijkste uitkomsten}

\author{
Bezwaren tegen indexering \\ In het Spelderholt-overleg zijn voorstellen gedaan om de jaarlijkse pachtnormen te stabiliseren door \\ middel van indexering. De voorgestelde koppeling van de pachtnormen aan de agrarische grondprijs \\ voorkomt niet dat grote schommelingen in de pachtnormen optreden. Een ander bezwaar is dat de \\ grondprijs de uitdrukking is van de marginale opbrengstwaarde van de landbouwgrond en niet van de \\ gemiddelde opbrengstwaarde. Verder staat de agrarische grondprijs onder invloed van de niet- \\ agrarische vraag naar grond en van de rentevoet. De indexering van pachtnormen met de \\ consumentenprijsindex (CPI) heeft als bezwaar dat de pachtnormen geen relatie hebben met de \\ wettelijke afspraak dat de bedrijfsuitkomsten leidend zijn. Door indexering met CPI wordt de kans op \\ een verlaging van de pachtnormen erg klein, terwijl de bedrijfsresultaten op- en neergaan.
}

\section{Grondbeloning als basis}

De pachtnormen variëren omdat ze gebaseerd zijn op de grondbeloning in de landbouw, die van jaar op jaar sterk kan variëren. De veranderingen in de pachtnormen worden behoorlijk afgevlakt door de middeling van de grondbeloning over vijf jaren. Verder zorgt de correctie voor de rendementseis voor enige demping. Mede dankzij de bovengrens ( $110 \%$ van de regionorm) en ondergrens ( $90 \%$ van de regionorm) voor de pachtprijzen, variëren de feitelijk betaalde pachtprijzen veel minder dan de pachtnormen. Uitbreiding naar een langere periode voor de berekening van de grondbeloning (in deze verkenning tot 6 en 7 jaar) heeft weinig invloed op de schommelingen. Binnen de huidige pachtprijzensystematiek - met als basis de grondbeloning - lijken daarmee weinig mogelijkheden te zijn om de volatiliteit van de pachtnormen verder af te vlakken, zonder afbreuk te doen aan het principe van het huidige systeem: dat de pachtnormen gebaseerd zijn op de grondbeloning.

\section{Andere mogelijkheden}

De pachtnormen kunnen gestabiliseerd worden door maximale veranderpercentages (en/of maximale bedragen per ha) per pachtprijsgebied vast te stellen. Ook is het denkbaar om het landelijk veranderpercentage (afgeleid van de grondbeloning per gebied) van toepassing te verklaren op alle pachtregio's. Dit komt overeen met de methode van het Pachtprijzenbesluit 1995, maar dan niet op basis van de grondprijs maar op basis van de grondbeloning. Aan deze suggestie kleeft het bezwaar dat de regionale verbijzondering aan gewicht verliest.

\section{S.2 Vraagstelling en methode}

Ondanks de stabiliserende elementen in de berekeningswijze van de pachtnormen, vertonen de uitkomsten van jaar op jaar flinke schommelingen. In opdracht van het ministerie van Economische Zaken heeft Wageningen Economic Research een analyse gemaakt van enkele opties om de normen te stabiliseren. Als uitgangspunt is de huidige situatie van de berekende pachtnormen en de feitelijk betaalde pachtprijzen in kaart gebracht. Vervolgens zijn de indexeringsvoorstellen in het Spelderholtoverleg doorgerekend. Ten slotte zijn opties verkend om wisselingen in pachtnormen op andere manieren te dempen. 


\section{$1 \quad$ Inleiding}

\section{$1.1 \quad$ Aanleiding}

In opdracht van het ministerie van Economische Zaken (EZ) berekent Wageningen Economic Research (voorheen LEI Wageningen UR) jaarlijks de pachtnormen, de hoogst toelaatbare pachtprijzen per pachtprijsgebied (Silvis et al., 2016). Ondanks de stabiliserende elementen in de berekeningswijze, vertonen de uitkomsten van jaar op jaar flinke schommelingen. Die schommelingen leveren discussie op, onder meer in het Spelderholt-overleg.

Spelderholt-overleg

In het vervolg op de evaluatie van het pachtrecht door prof. mr. D.W. Bruil hebben vertegenwoordigers van pachters en verpachters met elkaar gesproken over een vernieuwing van het pachtrecht. De initiatiefnemers van dit Spelderholt-overleg waren mr. W.L. Valk, mr. G.M.F. Snijders en mr. H.A. Verbakel-van Bommel. Begin juli 2014 werd een deelakkoord bereikt. Later zijn vervolggesprekken gevoerd over het overgangsrecht en de wijze van prijstoetsing van de diverse pachtvormen. Daarbij zijn FPG, LTO, ASR, Natuurmonumenten en LandschappenNL het eens geworden over een eindakkoord. De Bond van Landpachters en Eigen Grondgebruikers (BLHB) en het Nederlands Agrarisch Jongeren Kontakt (NAJK) hebben dit afgewezen.

Bij het deelakkoord van Spelderholt (juli 2014) is voorgesteld om de jaarlijkse wisselingen in de pachtnormen te verminderen aan de hand van de agrarische grondprijs. In de vervolgbesprekingen tussen de partijen van het akkoord van Spelderholt in de zomer van 2015 is de index ingevuld door de normwaarderingen van cultuurgronden voor de verschillende regio's zoals die door de Belastingdienst worden vastgesteld. In een later stadium is een aangepaste hoofdlijn 14 opgesteld. In plaats van op de regionale grondprijsontwikkeling, is de index gebaseerd op de consumentenprijsindex.

\subsection{Onderzoeksvragen}

Het ministerie van Economische Zaken (EZ) heeft behoefte aan een analyse van de voorgestelde indexeringsmethoden in het Spelderholt-overleg en hun effectiviteit (de verwachte impact). Daarnaast wil het ministerie inzicht in de mogelijkheden ('vingeroefeningen') om binnen het huidige grondbeloningsstelsel de volatiliteit van de pachtnormen af te kunnen vlakken. Om de impact van de verschillende opties inzichtelijk te maken, is gevraagd om een en ander met concrete voorbeelden door te rekenen.

\subsection{Aanpak}

De aanpak van het verkennen van de mogelijkheden voor het stabiliseren van de pachtnormen bestaat uit drie hoofdonderdelen:

a. Beschrijven en in kaart brengen van de huidige situatie van de berekende pachtnormen en de feitelijk betaalde pachtprijzen (hoofdstuk 2);

b. Analyseren van de indexering van de pachtnormen volgens de verschillende voorstellen uit het Spelderholt-overleg in 2014 en 2015: via de prijsontwikkeling van agrarisch onroerend goed (hoofdstuk 3), en via de consumentenprijsindex (hoofdstuk 4);

c. Verkennen van opties om wisselingen in pachtnormen te dempen binnen de bestaande systematiek (grondbeloningsstelsel) (hoofdstuk 5). 


\section{Fluctuaties in pachtnormen en pachtprijzen}

\section{$2.1 \quad$ Inleiding}

Dit hoofdstuk geeft een overzicht van de hoogst toelaatbare pachtprijzen - de pachtnormen - zoals die in de afgelopen jaren zijn vastgesteld conform het Pachtbesluit 2007. De schommelingen in de pachtnormen onder invloed van de inkomensfluctuaties in de landbouw zijn door de jaren heen een punt van aandacht geweest. Dat werd al onderkend bij de ontwikkeling van de rekensystematiek. Ook waren de fluctuaties aanleiding voor het aanbrengen van een aantal wijzigingen in de berekeningswijze, die hieronder worden toegelicht. Ten slotte worden de ontwikkelingen van de betaalde pachtprijzen in beeld gebracht.

\subsection{Pachtnormen}

\section{Berekening veranderpercentages}

In 2007 is de huidige systematiek ingevoerd voor de berekening van de hoogst toelaatbare pachtprijzen (pachtnormen) van reguliere pachtovereenkomsten en geliberaliseerde pachtovereenkomsten met een looptijd van meer dan zes jaar. Centraal in de berekening staat de grondbeloning (gebaseerd op het inkomen uit bedrijf). Deze wordt berekend als een gemiddelde over vijf jaar. Door de middeling worden de fluctuaties sterk gereduceerd (figuur 2.1). Na een correctie voor reserveringen en de rendementseis van de verpachter, resulteert de berekening in de pachtnorm per pachtprijsgebied (tabel B2.1, bijlage 2). Het veranderpercentage voor bestaande contracten wordt bepaald door de nieuwe regionorm te delen door de oude (voorgaande) regionorm (tabel B2.2, bijlage 2).

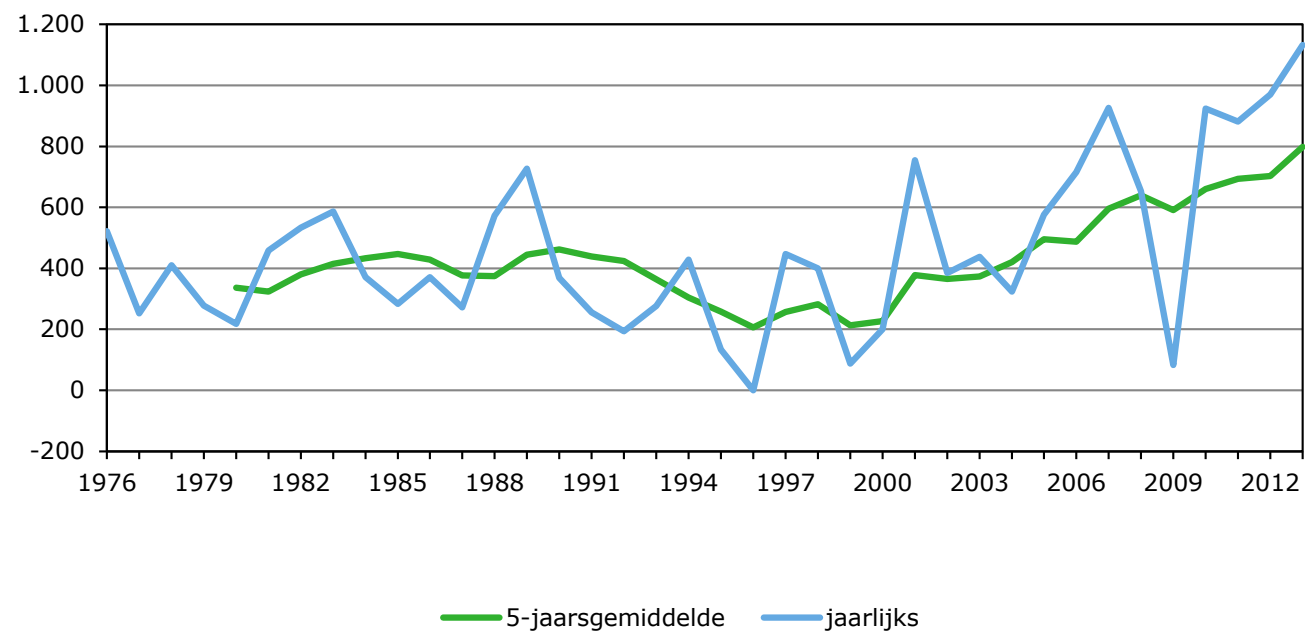

Figuur 2.1 Grondbeloning (euro/ha) na reservering per jaar en 5-jaars voortschrijdend gemiddelde Bron: Wageningen Economic Research.

\section{Tussentijdse aanpassingen}

In 2009 is de waardeverandering van de duurzame biologische activa uit het bedrijfsresultaat - en dus ook uit de grondbeloning - gehaald. Hiermee zijn (onnodige) schommelingen in de grondbeloning voorkomen. Verder is het aantal pachtprijsgebieden bij de berekening van de pachtnormen van 2009 uitgebreid van 8 naar 14 . Ook is in 2009 een plafond voor de prijs van bestaande pachtovereenkomsten 
ingevoerd: die mag niet meer dan $10 \%$ uitstijgen boven de regionorm. Als de pachtprijs daar al boven ligt, wordt de prijs bevroren.

\section{Bes/uiten op advies Commissie pachtnormen II}

In 2010 heeft de minister van LNV de Commissie pachtnormen II ingesteld met als taak knelpunten in de pachtprijzensystematiek te inventariseren en mogelijke oplossingen te verkennen. De kern van deze zogenaamde 'finetuning' was de problematiek van de sterk fluctuerende regionormen en veranderpercentages. De aanbevelingen van de Commissie pachtnormen II zijn aanvaard als een samenhangend pakket, waarin rekening is gehouden met de belangen van pachters en verpachters. De hoofdpunten waren de volgende:

\section{- afschrijving melkquotum}

Bij de berekening van de grondbeloning wordt niet langer afgeschreven over aangekocht melkquotum. Het in rekening brengen van deze afschrijvingskosten zou een substantiële en tijdelijke invloed hebben op de hoogte van de grondbeloning, omdat de afschrijving bij het einde van de melkquotering in april 2015 zou stoppen.

- reservering

Vanaf 2011 wordt de reservering niet meer als percentage (1\%) van het pachtersvermogen berekend, maar als percentage (20\%) van de grondbeloning. Het voordeel is dat de fluctuatie van de grondbeloning in de tijd wordt afgezwakt.

\section{- ondergrens}

Naast de bestaande $110 \%$-bovengrens is een ondergrens van $90 \%$ ingevoerd. Deze grens houdt in dat de pachtprijs van bestaande overeenkomsten niet meer dan $10 \%$ onder de regionorm mag zakken. Als de prijs daar al onder zit, wordt die bevroren. De plafonds - $90 \%$ en $110 \%$ van de regionorm - leiden in de toekomst tot een minder grote spreiding in pachtprijzen.

\section{Oorzaken van schommelingen}

In tabel B1.1 (bijlage 1) is de gemiddelde grondbeloning na reservering opgenomen. In 2010 zijn er geen pachtnormen berekend (in verband met tweejaarlijkse herziening). Vanaf 2011 worden de pachtnormen jaarlijks berekend en is de berekeningswijze niet meer gewijzigd. In de bijlagetabel B1.2 zijn de veranderingen (in \%) van de grondbeloning ten opzichte van de voorgaande periode opgenomen.

De bijlagen laten zien dat de grondbeloning behoorlijk fluctueert in de tijd en naar gebied. Dat heeft alles te maken met de sterke schommelingen van de inkomens in de melkveehouderij en de akkerbouw. De besproken maatregelen om de veranderingen in de grondbeloning af te zwakken, met als belangrijkste de middeling over meer jaar (vijf), doen wel hun werk, maar voorkomen niet dat relatief grote wisselingen optreden.

De pachtnormen worden niet alleen bepaald door de grondbeloning maar ook door de rendementseis. Door de sterk gedaalde rentevoet is deze eis in de jaren 2012-2015 sterk afgenomen. Hierdoor is de grondbeloning in de meeste pachtprijsgebieden naar beneden bijgesteld. In de jaren 2012 en 2013 heeft dat een dempende werking gehad op de veranderingen in de grondbeloning. Hierbij moet worden aangetekend dat de lagere rente op zichzelf een opwaarts effect heeft op de grondbeloning.

\subsection{Betaalde pachtprijzen}

De doorwerking van de pachtnormen in de praktijk is af te meten aan de ontwikkeling van de betaalde pachtprijzen. De hoogst toelaatbare pachtprijzen zijn van toepassing op reguliere pachtovereenkomsten en geliberaliseerde pacht langer dan zes jaar. In tabel B3.1 (bijlage 3) zijn de betaalde prijzen van deze pachtovereenkomsten opgenomen, en in bijlagetabel B3.2 de jaarlijkse procentuele veranderingen.

De betaalde pachtprijzen fluctueren veel minder dan de pachtnormen (vergelijk tabel B2.2 en B3.2). Dat wordt onder meer verklaard door de introductie van wettelijke plafonds. Door toepassing van het veranderpercentage mag de nieuwe pachtprijs niet uitstijgen boven $110 \%$ of dalen onder de $90 \%$ van de regionorm. Als de pachtprijs al boven de $110 \%$-grens of onder de $90 \%$-grens ligt, dan wordt de 
pachtprijs bevroren. Naast deze twee grenzen toetst de grondkamer bij een herzieningsverzoek of de prijs niet hoger is dan $2 \%$ van de vrije verkeerswaarde. De laagste van beide plafonds ( $110 \%$ en $2 \%$ ) geldt. Verder mogen de verpachters de veranderpercentages toepassen (binnen de plafonds), maar zijn ze daartoe niet verplicht.

Tabel 2.1 en 2.2 geven een samenvattend overzicht van de wijzigingen van de grondbeloning, pachtnorm en betaalde pachtprijs, in relatieve (tabel 2.1) en absolute (tabel 2.2) zin.

Ter toelichting: in 2013 is in drie gebieden de grondbeloning met minder dan $10 \%$ veranderd (ten opzichte van 2012), in positieve of negatieve zin (tabel 2.1). De pachtnorm is in dat jaar in zes gebieden met minder dan 10\% gewijzigd en de betaalde pachtprijs week in 2013 in elf gebieden niet meer dan $10 \%$ af van de pachtprijs in 2012. In tabel 2.2 is de wijziging uitgedrukt in euro per ha met als klassen minder dan 50 euro per ha (positief of negatief), 50 tot 100 euro en meer dan 100 euro. De basisinformatie is terug te vinden in bijlagen 1 tot en met 3 .

Tabel 2.1 Aantal pachtprijsgebieden naar procentuele wijziging grondbeloning, pachtnorm en betaalde pachtprijs

\begin{tabular}{|c|c|c|c|c|}
\hline & 2011 & 2012 & 2013 & 2014 \\
\hline \multicolumn{5}{|c|}{ Grondbeloning in \% (+/-) } \\
\hline$<10$ & 7 & 6 & 3 & 7 \\
\hline$>20$ & 2 & 7 & 5 & 3 \\
\hline \multicolumn{5}{|c|}{ Pachtnorm in \% (+/-) } \\
\hline $10-20$ & 5 & 4 & 5 & 4 \\
\hline$>20$ & 1 & 1 & 3 & 2 \\
\hline \multicolumn{5}{|c|}{ Betaalde pachtprijs in $\%(+/-)$} \\
\hline$<10$ & 12 & 10 & 11 & 9 \\
\hline $10-20$ & 2 & 3 & 2 & 6 \\
\hline
\end{tabular}

Bron: Wageningen Economic Research.

Het dempende effect van de correctie voor de rendementseis in 2012 en 2013 is in de tabellen terug te zien, evenals de minder sterke doorwerking van de pachtnormen in de pachtprijzen.

Tabel 2.2 Aantal pachtprijsgebieden naar absolute wijziging grondbeloning, pachtnorm en betaalde pachtprijs

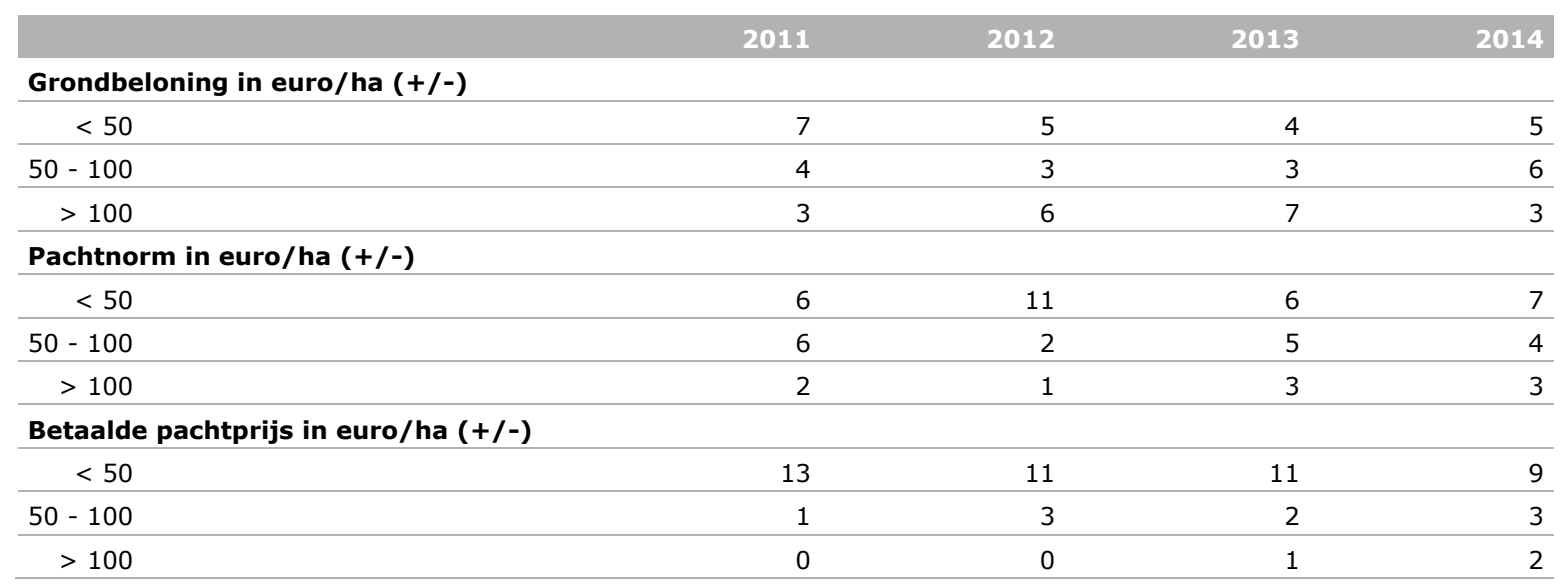

Bron: Wageningen Economic Research. 
In figuur 2.2 zijn de grondbeloning, pachtnorm en betaalde pacht op landelijk niveau naast elkaar gezet. De pachtnormlijn start in 2011, omdat vanaf dat jaar de pachtnormen ieder jaar worden berekend volgens dezelfde systematiek. De overeenkomstige figuren per pachtprijsgebied staan in bijlage 4 .

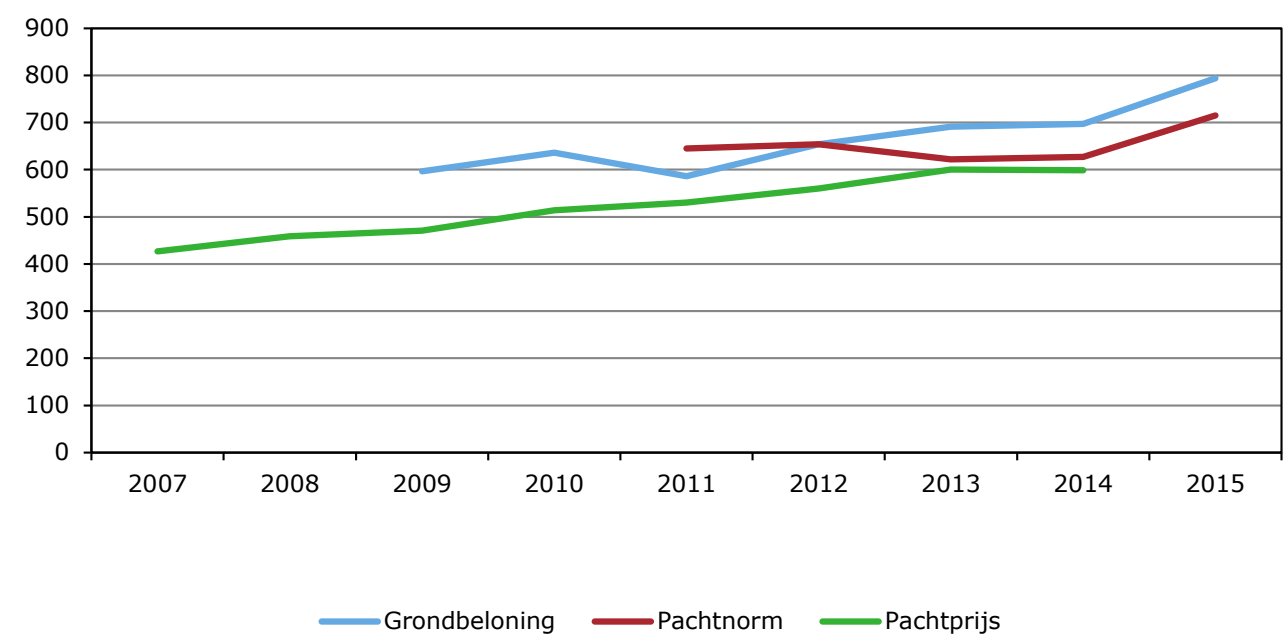

Figuur 2.2 Gemiddelde grondbeloning (5-jaarsgemiddelde), pachtnorm en pachtprijs (euro/ha) in Nederland

Bron: Wageningen Economic Research.

De feitelijke pachtprijzen blijken veel minder te variëren dan de pachtnormen (figuur 2.2). Dat is mede te danken aan de introductie van de bovengrens ( $110 \%$ van de regionorm) en ondergrens ( $90 \%$ van de regionorm). Daarnaast speelt mee hoe de verpachters de pachtnormen laten doorwerken in de prijzen van pachtovereenkomsten. Voor de uitkomsten per regio wordt verwezen naar de bijlage 4.

\subsection{Conclusie}

De pachtnormen verschillen van jaar op jaar en tussen de pachtprijsgebieden. Dat is inherent aan de gekozen grondslag voor de pachtnormen: de grondbeloning die gebaseerd is op de bedrijfswinst uit normale bedrijfsvoering. Die maatstaf hangt nauw samen met het 'inkomen uit bedrijf'. Dat inkomen kan in de melkveehouderij en akkerbouw van jaar op jaar sterk variëren. Om al te grote schommelingen in de pachtnormen te voorkomen, zijn enkele maatregelen getroffen. De belangrijkste daarvan is de middeling van de grondbeloning over vijf jaren. Dat vlakt de veranderingen behoorlijk af. De correctie voor de rendementseis heeft in enkele jaren voor een lichte demping gezorgd. De feitelijke pachtprijzen variëren veel minder dan de pachtnormen. Dat is mede te danken aan de introductie van een boven- ( $110 \%$ van de regionorm) en ondergrens ( $90 \%$ van de regionorm). Daarnaast speelt mee dat de pachtnormen niet automatisch doorwerken in de prijzen van pachtovereenkomsten. 


\section{Indexering met agrarische grondprijs}

\subsection{Inleiding}

In het deelakkoord van Spelderholt I (juli 2014) is voorgesteld het veranderpercentage voor de pachtprijs van bestaande pachtovereenkomsten voor los land op een andere wijze te berekenen. Dat is uitgewerkt in hoofdlijn 14 :

Voor bestaande reguliere pachtovereenkomsten is de pachtprijs voor land af te leiden van het gemiddelde van de pachtprijzen sinds 2007, te vermeerderen met een index die wordt afgeleid van de prijsontwikkeling van agrarisch onroerend goed (daarmee horen de huidige pieken en dalen tot het verleden). Het landelijk gemiddelde van de pachtprijzen voor het eerste jaar volgens de nieuwe systematiek is niet hoger of lager dan het landelijk gemiddelde van de pachtprijzen van het jaar ervoor, behalve volgens hetgeen past bij de ontwikkeling van het prijspeil.

Agrarisch Recht (artikel) - Het Akkoord van Spelderholt Een toelichting op het akkoord van Spelderholt is gegeven in Agrarisch Recht (Valk et al., 2014). Over de nieuwe wijze van het berekenen van het veranderpercentage voor los land (hoofdlijn 14) is het volgende opgenomen:

Herziening van rechtswege van bestaande reguliere pachtovereenkomsten vindt straks wat betreft de pachtprijs van land plaats volgens een eenvoudig mechanisme dat aansluit bij de huidige pachtprijzen, maar zonder de jaarlijkse pieken en dalen (punt 14 van het akkoord). Voor alle bestaande pachtovereenkomsten zal voor de pachtprijs van land jaarlijks een veranderpercentage gelden (dus ook voor de pachtovereenkomst die na 1 september 2007 zijn aangegaan). Dat veranderpercentage wordt in het eerste jaar van het nieuwe stelsel afgeleid van het gemiddelde van de pachtprijzen sinds 2007, gecorrigeerd voor de ontwikkeling van het prijspeil. Pachters die juist meerdere pachtprijsverhogingen achter de rug hebben, zullen een negatief veranderpercentage tegemoet kunnen zien. Pachters die juist meerdere verlagingen achter de rug hebben, moeten met een prijsverhoging rekening houden. De veranderpercentages in volgende jaren worden afgeleid van de prijsontwikkeling van agrarisch onroerend goed. Het akkoord behoeft op dit punt nog de nodige uitwerking: de veranderpercentages van het eerste jaar moeten worden berekend en de systematiek van de index van de prijs van agrarisch onroerend goed moet worden ontwikkeld (waarbij het voor hand ligt om rekening te houden met regionale verschillen in de prijsontwikkeling).

In de vervolgbesprekingen tussen de partijen van het akkoord van Spelderholt in de zomer van 2015 (Spelderholt II) is een alternatieve invulling geopperd:

Die index kan worden afgeleid van de normwaarderingen van cultuurgronden door de belastingdienst in de verschillende regio's (daarmee behoren de huidige pieken en dalen tot het verleden).

\subsection{Uitwerking systematiek}

Het voorstel heeft uitsluitend betrekking op het berekenen van de pachtnormen van bestaande reguliere overeenkomsten (voor en ná 1 september 2007 aangegaan) in de vorm van veranderpercentages (en geen absolute pachtnormen). In het eerste jaar van deze systematiek wordt het veranderpercentage berekend op basis van de vastgestelde pachtnormen vanaf 2007 tot en met 
2014. Vervolgens worden de veranderpercentages afgeleid van de prijsontwikkeling van agrarisch onroerend goed (voorstel Spelderholt I).

Veranderpercentage eerste jaar

Het veranderpercentage voor het eerste jaar wordt als volgt bepaald:

1. gemiddelde pachtnorm per pachtprijsgebied over de periode 2007-2014. Daarbij zijn voor 2008 dezelfde pachtnormen genomen als in 2007 en voor 2010 die van 2009 (periode met

tweejaarlijkse vaststelling van de pachtnormen). In 2007 en 2008 zijn er 8 pachtprijsgebieden, opgebouwd uit de huidige 14 pachtprijsgebieden. De pachtprijsgebieden die in een samengesteld pachtprijsgebied vallen krijgen in 2007 en 2008 dezelfde pachtnorm;

2. landelijke gemiddelde pachtnorm over 2007-2014. Dat is het gemiddelde van de gemiddelde pachtnorm over 2007-2014 van de 14 pachtprijsgebieden (uit 1);

3. landelijke gemiddelde pachtnorm in 2014. Dat is het gemiddelde van de pachtnorm in 2014 van de 14 pachtprijsgebieden;

4. 'correctiepercentage'. Dit percentage wordt berekend door resultaat van (3) te delen door resultaat van (2);

5. met het correctiepercentage (4) wordt de gemiddelde pachtnorm over 2007-2014 per pachtprijsgebied (1) aangepast;

6. veranderpercentage eerste jaar. Deze wordt berekend door (5) te delen door de pachtnorm van 2014 per pachtprijsgebied.

Veranderpercentages na eerste jaar

De indexering (veranderpercentages) na het eerste jaar ' ... wordt afgeleid van de prijsontwikkeling van agrarisch onroerend goed', ... 'waarbij het voor hand ligt om rekening te houden met regionale verschillen in de prijsontwikkeling' (Valk et al., 2014). In Spelderholt II is een nadere invulling gegeven aan de index: 'Die index kan worden afgeleid van de normwaarderingen van cultuurgronden door de belastingdienst in de verschillende regio's.' Voor de verdere uitwerking gaan we uit van deze specificering.

De Belastingdienst publiceert jaarlijks cijfers - normwaarden - voor de waardering van verpachte gronden in box 3. In de belastingjaren 2010 en 2011 werden deze voor de 14 groepen van landbouwgebieden gegeven, daarna voor de 66 landbouwgebieden. Het gaat hierbij om prijzen voor onverpacht gras- en bouwland die ten behoeve van de landbouw worden gebruikt. Tot 2015 werden de gegevens voor de waardering aangeleverd door de Dienst Landelijk Gebied (DLG). Voor het belastingjaar 2015 hebben het Kadaster en Wageningen Economic Research (voorheen LEI) deze taak opgepakt. De organisaties werken samen om de informatievoorziening over de agrarische grondmarkt te waarborgen (na opheffing van DLG).

Voor inzicht in de effecten van een indexering (veranderpercentages) van de pachtnormen op basis van de ontwikkeling van de agrarische grondprijzen, wordt gebruik gemaakt van informatie uit de database van de agrarische grondmarkt van het Kadaster en Wageningen Economic Research. Dat is mogelijk vanaf 2012. Voor de jaren daarvoor is teruggevallen op bestanden van DLG. De indexcijfers worden berekend vanaf 2007, het jaar waarin de huidige pachtnormberekening is ingevoerd.

\subsection{Toepassing systematiek}

Veranderpercentage eerste jaar

Het resultaat van stap (1) - zie voorgaande paragraaf - is opgenomen in tabel 3.1. De landelijke gemiddelde pachtnorm over 2007-2014 (stap 2) bedraagt 596 euro per ha, en die voor 2014633 euro per ha (stap 3). Het correctiepercentage (stap 4) bedraagt (633/596) 6,21\%. Met dit percentage wordt de gemiddelde pachtnorm van 2007-2014 (stap 1) per pachtprijsgebied verhoogd (stap 5). Het veranderpercentage voor het eerste jaar per pachtprijsgebied (stap 6) wordt berekend uit het verschil van de gemiddelde pachtnorm 2007-2014 na correctie (stap 5) en de kolom met de pachtnorm 2014. 
Tabel 3.1

Pachtnormen (euro/ha) en veranderpercentages eerste jaar bij voorstel Spelderholt I

\begin{tabular}{|c|c|c|c|c|}
\hline & Pachtnorm 2014 & Pachtnorm & 2007-2014 & (6) Verander $\%$ \\
\hline & & (1) gemiddeld & (5) na correctie & \\
\hline Bouwhoek en Hogeland & 604 & 603 & 641 & 6 \\
\hline Noordelijk weidegebied & 652 & 588 & 625 & -4 \\
\hline Oostelijk veehouderijgebied & 527 & 572 & 608 & 15 \\
\hline IJsselmeerpolders & 941 & 890 & 945 & 0 \\
\hline Westelijk Holland & 542 & 457 & 486 & -10 \\
\hline Waterland en Droogmakerijen & 315 & 434 & 460 & 46 \\
\hline Hollands/Utrechts weidegebied & 708 & 570 & 605 & -15 \\
\hline Zuidelijk veehouderijgebied & 645 & 671 & 713 & 11 \\
\hline Zuid-Limburg & 854 & 667 & 709 & -17 \\
\hline Landelijk gemiddelde & 633 & 596 & 633 & 3 \\
\hline
\end{tabular}

Bron: Wageningen Economic Research.

In figuur 3.1 zijn de pachtnormen van 2014 en de gecorrigeerde pachtnormen naast elkaar geplaatst. Het effect van de herberekening is dat de bestaande verschillen tussen de pachtnormen van de gebieden (enigszins) wordt verkleind. Voor IJsselmeerpolders levert de herberekening geen verschil op. Voor Waterland en Droogmakerijen komt een verhoging van 46\% uit de bus. Minder groot, maar toch fors zijn de veranderpercentages voor Veenkoloniën en Oldambt $(-19 \%)$ en Zuid-Limburg $(-17 \%)$.

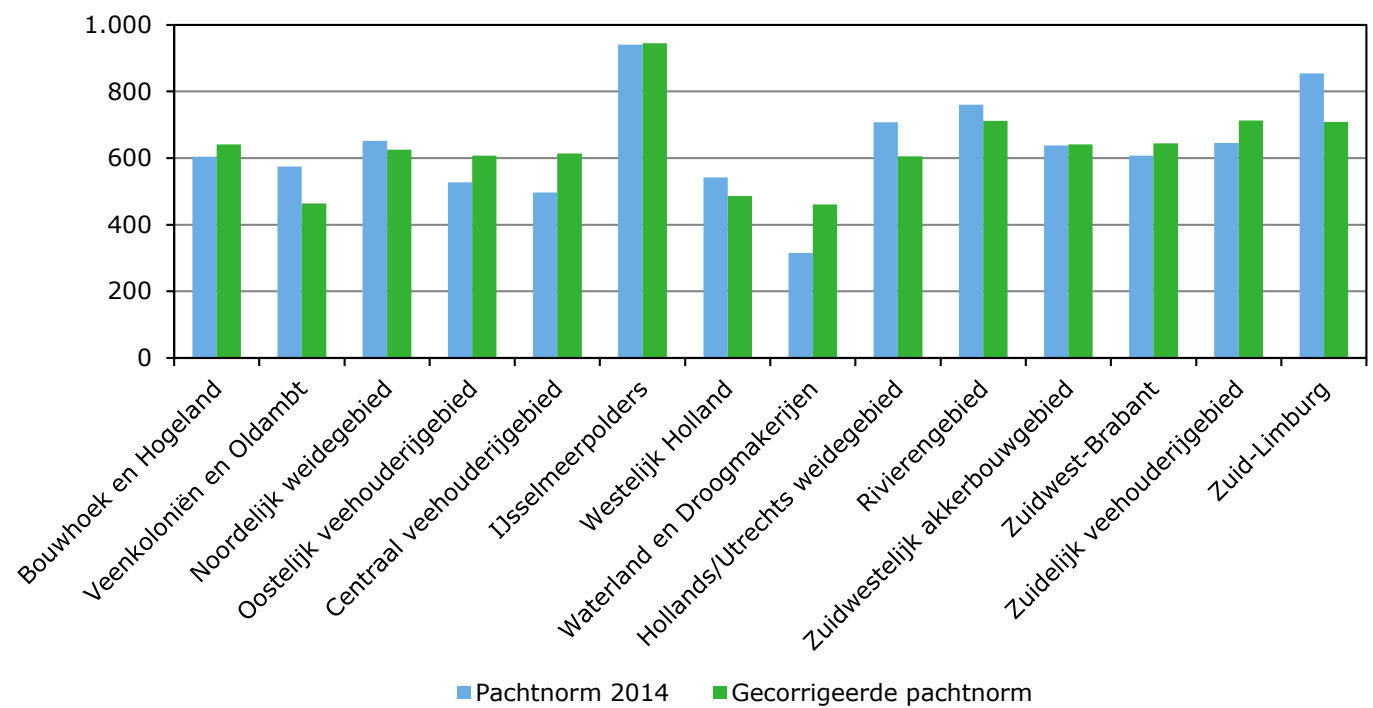

Figuur 3.1 Pachtnormen 2014 en gecorrigeerde pachtnormen (volgens Spelderholt) Bron: Wageningen Economic Research.

Veranderpercentages na eerste jaar

Het resultaat van het gebruik van de ontwikkeling van de agrarische grondprijs voor het bepalen van de veranderpercentages is opgenomen in tabel 3.2. Dit is een proefberekening toegepast op oude jaren ter illustratie van wat het effect van dit systeem zou zijn geweest. In de eerste drie jaar (20082010) in dit voorbeeld zijn de mutaties ook behoorlijk groot. Na 2011 het verloop veel gematigder, omdat de agrarische grondprijs in de laatste jaren een rustiger ontwikkeling heeft gekend. Dat is echter geen garantie voor een stabiele ontwikkeling in de toekomst. 
Tabel 3.2 Jaarlijkse verandering pachtnormen (\%) op basis van de agrarische grondprijs, 20082014

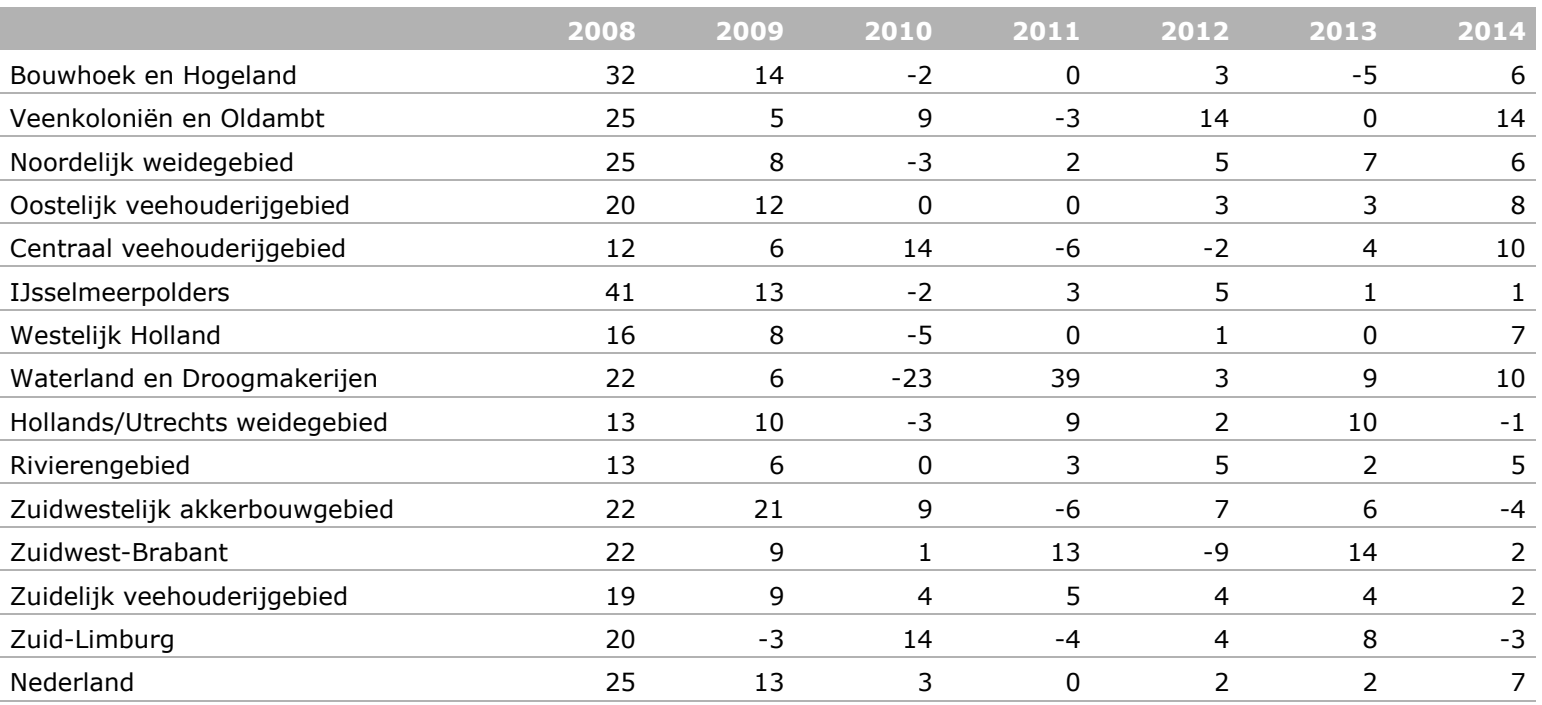

Bron: Wageningen Economic Research.

Over een lange periode is de agrarische grondprijs trendmatig gestegen, onderbroken door perioden waarin de prijs stijgt of daalt. Zo verdubbelde de gemiddelde landelijke grondprijs tussen 1995 en 2000 (van circa 18.000 naar 36.000 euro per ha). Daarna nam de prijs af tot 29.000 euro per ha $(-20 \%)$, om vervolgens weer te stijgen met $65 \%$ tot 48.000 euro per ha in 2010 en circa 55.000 in 2015. Kortom, het gebruik van de ontwikkeling van de agrarische grondprijs voor het bepalen van de veranderpercentages is allerminst een garantie voor stabiele pachtnormen.

\subsection{Conclusie}

In de akkoorden van Spelderholt (I en II) is een nieuwe systematiek voor het berekenen van de hoogst toelaatbare pachtprijzen - de pachtnormen - voorgesteld. In een eerste stap wordt voor het startjaar een veranderpercentage berekend dat bedoeld is als een correctie op de pachtnormen die in de afgelopen jaren zijn ingevoerd. Het is niet duidelijk waarom dat nodig is. Voor de jaren daarna wordt voorgesteld het veranderpercentage te baseren op de ontwikkeling van de regionale agrarische grondprijs. Deze koppeling voorkomt niet dat grote schommelingen in de pachtnormen optreden. Hiervoor kan worden verwezen naar de ervaringen in de periode tussen 1995 en 2007 met het afleiden van pachtnormen van de ontwikkeling van de agrarische grondprijs. Er kunnen ook principiële bezwaren tegen de grondprijsontwikkeling als maatstaf voor indexering worden aangevoerd. De grondprijs is de uitdrukking van de marginale opbrengstwaarde van de landbouwgrond en niet van de gemiddelde opbrengstwaarde. Verder staat de agrarische grondprijs onder invloed van de nietagrarische vraag naar grond (afhankelijk van tijd en plaats) en van het monetaire beleid (rentevoet). Mede hierdoor kan de agrarische grondprijs behoorlijk schommelen, zoals het verleden laat zien. 


\title{
$4 \quad$ Indexering via consumentenprijsindex
}

\section{$4.1 \quad$ Inleiding}

In een later stadium van het Spelderholt-overleg is een aangepaste hoofdlijn 14 opgesteld. Hierin wordt de index, in plaats van op de regionale grondprijsontwikkeling, gebaseerd op de consumentenprijsindex. De herziene hoofdlijn 14 luidt:

\begin{abstract}
Binnen de opdracht aan de regelgever van art. 7:327 lid 2 BW (namelijk bevordering van pachtprijzen welke in een redelijke verhouding staan tot de bedrijfsuitkomsten bij een behoorlijke bedrijfsvoering, met mede inachtneming van de redelijke belangen van de verpachter), wordt de prijs van bestaande reguliere pachtovereenkomsten met ingang van het tweede jaar van het nieuwe stelsel van rechtswege herzien volgens de consumentenprijsindex (daarmee behoren de huidige pieken en dalen tot het verleden). Het veranderpercentage voor het eerste jaar van het nieuwe stelsel wordt per pachtprijsgebied bepaald aan de hand van het gemiddelde van de pachtprijzen sinds 2007, te corrigeren voor de kostenontwikkeling sinds 2007 aan de hand van de consumentenprijsindex.
\end{abstract}

\subsection{Uitwerking systematiek}

In het voorstel voor indexering met de consumentenprijsindex (CPI) worden de pachtnormen voor het eerste jaar herberekend en vervolgens gewijzigd aan de hand van de CPI. Het voorstel heeft uitsluitend betrekking op het berekenen van de pachtnormen van bestaande reguliere overeenkomsten (voor en ná 1 september 2007 aangegaan) in de vorm van veranderpercentages (geen absolute pachtnormen).

De veranderpercentages voor het eerste jaar worden als volgt bepaald:

1. de gemiddelde pachtnormen per pachtprijsgebied over de periode 2007-2015 zijn uitgangspunt. Daarbij zijn voor 2008 dezelfde pachtnormen genomen als in 2007 en voor 2010 die van 2009. In die periode werden de normen iedere twee jaren aangepast. In 2007 en 2008 zijn er acht pachtprijsgebieden, die later zijn verdeeld in de huidige 14 pachtprijsgebieden. De pachtprijsgebieden die in een samengesteld pachtprijsgebied vallen krijgen in 2007 en 2008 dezelfde pachtnorm;

2. pachtnormen per jaar (2007-2015) worden geïndexeerd met de consumentenprijsindex (CPI) (prijspeil 2015);

3. geïndexeerde pachtnormen uit stap (2) worden gemiddeld;

4. de veranderpercentages van het eerste jaar worden verkregen door de pachtnormen uit stap (3) te delen door de pachtnormen in 2015.

Veranderpercentages na eerste jaar Vanaf het tweede jaar is er nog slechts één veranderpercentage, de inflatie op basis van de CPI. Dat wil zeggen dat vanaf het tweede jaar de aanpassing van de hoogst toelaatbare pachtprijs voor alle pachtprijsgebieden gelijk is. Hoewel dat niet expliciet is opgenomen in de hiervoor aangehaalde hoofdlijn 14, wordt aangenomen dat de aanpassing jaarlijks plaatsvindt. 


\subsection{Toepassing systematiek}

\section{Veranderpercentage eerste jaar}

In tabel 4.1 zijn de resultaten opgenomen voor de berekening van het eerste jaar. De eerste kolom bevat de pachtnormen van 2015. In de tweede kolom staan de gemiddelde pachtnormen in de periode 2007-2015, na indexatie met de CPI (uitkomst van stap 3). In de derde kolom is het veranderpercentage opgenomen (uitkomst van stap 4). Dit percentage - geïndexeerde gemiddelde pachtnormen (3) delen door pachtnormen 2015 - loopt uiteen van -29\% in Veenkoloniën en Oldambt tot $+17 \%$ in Waterland en Droogmakerijen.

Tabel 4.1 Pachtnormen (euro/ha) en veranderpercentages eerste jaar (volgens voorstel Spelderholt II)

\begin{tabular}{|c|c|c|c|}
\hline & Pachtnormen 2015 & $\begin{array}{l}\text { (3) Gemiddelde pacht- } \\
\text { normen 2007-2015, na } \\
\text { indexatie met CPI }\end{array}$ & $\begin{array}{r}\text { (4) Veranderpercentage } \\
\text { ( } \%)\end{array}$ \\
\hline Veenkoloniën en Oldambt & 689 & 491 & -29 \\
\hline Noordelijk weidegebied & 738 & 641 & -13 \\
\hline Centraal veehouderijgebied & 622 & 621 & 0 \\
\hline IJsselmeerpolders & 1.174 & 977 & -17 \\
\hline Westelijk Holland & 660 & 509 & -23 \\
\hline Waterland en Droogmakerijen & 394 & 460 & 17 \\
\hline Hollands/Utrechts weidegebied & 819 & 631 & -23 \\
\hline Zuidwest-Brabant & 734 & 661 & -10 \\
\hline Zuidelijk veehouderijgebied & 751 & 725 & -3 \\
\hline Zuid-Limburg & 935 & 738 & -21 \\
\hline
\end{tabular}

Bron: Wageningen Economic Research.

Veranderpercentages na eerste jaar

$\mathrm{Na}$ het eerste jaar worden de pachtnormen per pachtprijsgebied met hetzelfde veranderpercentage de inflatie - aangepast. Op basis van de ervaringen van de afgelopen jaren zal dat neerkomen op een regelmatige verhoging.

\subsection{Conclusie}

Volgens de herziene hoofdlijn 14 wordt de prijs van bestaande reguliere pachtovereenkomsten aangepast met de consumentenprijsindex (CPI). De voorgestelde berekening van de veranderpercentages in het eerste jaar is een mengeling van pachtnormen uit verschillende jaren (gebaseerd op de grondbeloning) en de prijsontwikkeling van goederen en diensten aangeschaft door een gemiddeld huishouden voor consumptie. De veranderingen voor het eerste jaar zijn niet gemotiveerd. Zoals wettelijk bepaald, reflecteren de bestaande pachtnormen de grondbeloning in de voorafgaande vijfjarige periode. Vanaf het tweede jaar wordt de aanpassing van de pachtnormen gebaseerd op de CPI. De CPI is geen indicator van de bedrijfsuitkomsten in de landbouw. De berekeningswijze heeft dan ook geen relatie met de wettelijke doelstelling om de bedrijfsuitkomsten leidend te laten zijn. Indexering met CPI betekent dat de kans op een verlaging van de pachtnormen erg klein wordt. In de afgelopen 50 jaar is de inflatie - de procentuele jaar-op-jaar ontwikkeling van de consumentenprijsindex - slechts eenmaal negatief geweest. De monetaire autoriteiten doen er alles aan om deflatie te voorkomen. Daarentegen gaan de bedrijfsresultaten op en neer. 


\section{Aanpassingen in grondbeloningsstelsel}

\section{$5.1 \quad$ Inleiding}

In hoofdstuk 2 is uitgelegd dat de pachtnormen gebaseerd zijn op het 5-jaars voortschrijdend gemiddelde van de grondbeloning. In dit hoofdstuk wordt het effect nagegaan van een uitbreiding van het aantal jaren waarover de grondbeloning wordt gemiddeld, namelijk naar 6 en 7 jaar. Ook worden enkele andere opties geschetst om de pachtnormen te stabiliseren.

\subsection{Extra middeling}

De uitbreiding van het aantal jaren in het voortschrijdend gemiddelde draagt niet veel meer bij aan een demping van de schommelingen (figuur 5.1).

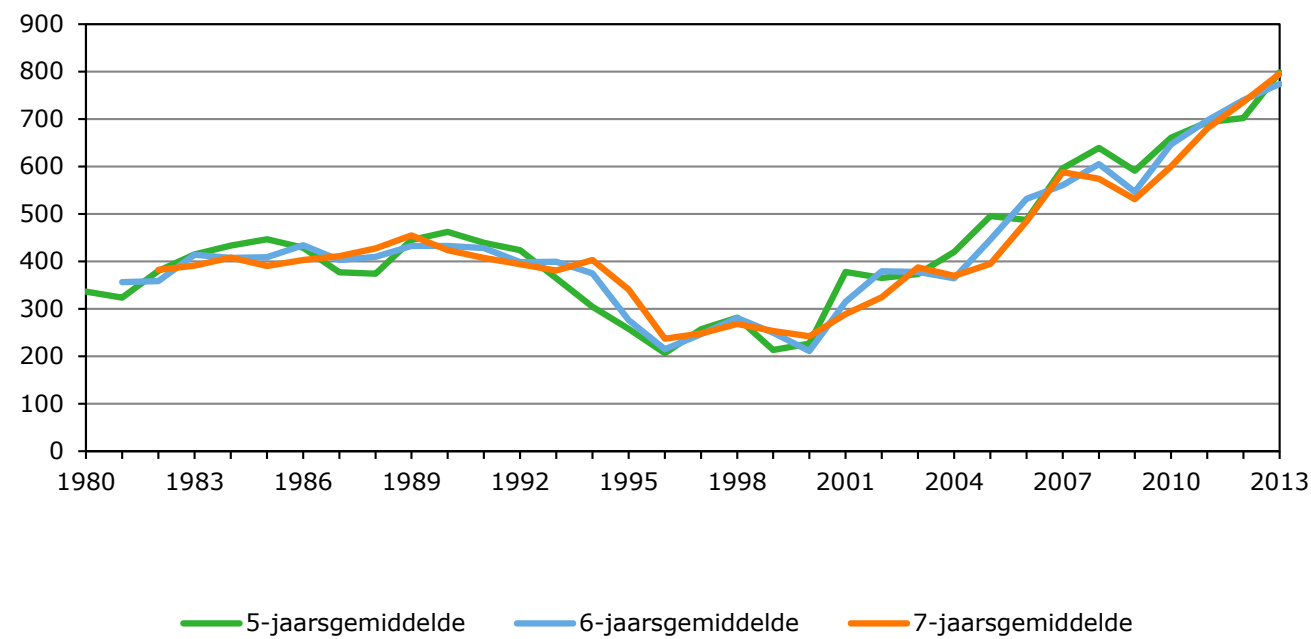

Figuur 5.1 Grondbeloning (euro/ha) na reservering, meerjarig voortschrijdende gemiddelden Bron: Wageningen Economic Research.

De veranderpercentages in 2014 en 2015 bij toepassing van 6- en 7-jaarsmiddeling van de grondbeloning zijn weergegeven in tabel 5.1 (zie ook tabel B2.2). Voor de getoonde jaren lopen de percentages uiteen van $-11 \%$ tot $+28 \%$ bij het 6 -jaarsgemiddelde, en van $-8 \%$ tot $+29 \%$ bij het 7-jaarsgemiddelde. 
Tabel 5.1 Veranderpercentage pachtnorm op basis 6- en 7-jaarsmiddeling grondbeloning, 2014 en 2015

\begin{tabular}{|c|c|c|c|c|}
\hline & \multicolumn{2}{|c|}{ 6-jaarsgemiddelde } & \multicolumn{2}{|c|}{ 7-jaarsgemiddelde } \\
\hline & 2014 & 2015 & 2014 & 2015 \\
\hline Bouwhoek en Hogeland & -2 & 3 & 11 & 4 \\
\hline Noordelijk weidegebied & 5 & 4 & 4 & 12 \\
\hline Oostelijk veehouderijgebied & 9 & 1 & 1 & 14 \\
\hline IJsselmeerpolders & 3 & 9 & 23 & -4 \\
\hline Westelijk Holland & 16 & 28 & 11 & 29 \\
\hline Waterland en Droogmakerijen & -11 & 17 & -8 & 22 \\
\hline Hollands/Utrechts weidegebied & 9 & 8 & 7 & 16 \\
\hline Zuidelijk veehouderijgebied & 8 & 10 & 4 & 19 \\
\hline Zuid-Limburg & 22 & 4 & 23 & 10 \\
\hline Nederland & 7 & 4 & 8 & 8 \\
\hline
\end{tabular}

Bron: Wageningen Economic Research.

De vergroting van het aantal jaren heeft slechts een gering dempend effect op de schommelingen in de grondbeloning. Als gevolg daarvan blijft de volatiliteit van de pachtnormen bestaan.

\subsection{Andere mogelijkheden}

Gezien de bezwaren tegen de verschillende voorstellen om de pachtnormen te stabiliseren, komt de vraag op of er nog andere mogelijkheden zijn. Er valt te denken aan het instellen van maximale veranderpercentages (en/of maximale bedragen per ha) per pachtprijsgebied. Ook is het denkbaar om het landelijk veranderpercentage van toepassing te verklaren op alle pachtregio's. Dit komt overeen met de methode van het Pachtprijzenbesluit 1995, maar dan niet op basis van de grondprijs maar op basis van de grondbeloning. Hierbij wordt de landelijke verandering (\%) van de grondbeloning afgeleid van de gewogen grondbeloning per gebied. Aan deze suggestie kleeft het bezwaar dat de regionale verbijzondering aan gewicht verliest. Zoals hiervoor geopperd bij de optie van een begrenzing per pachtprijsgebied, zou een politiek besluit kunnen volgen om het berekende veranderpercentage aan een maximum te binden eventueel in combinatie met een maximumbedrag per ha, en met de regionorm als grens. 


\section{Literatuur en websites}

CP I (Commissie pachtnormen I) (2006). Evenwicht in pachtnormen; Advies Commissie pachtnormen.

CP II (Commissie pachtnormen II) (2010). De prijs van pacht; Nadere bezinning op Evenwicht in pachtnormen.

Silvis, H.J., R.W. van der Meer en M.J. Voskuilen (2016). Pachtnormen 2016; Berekening hoogst toelaatbare pachtprijzen voor los land, agrarische bedrijfsgebouwen en agrarische woningen. Wageningen, LEI Wageningen UR (University \& Research centre), LEI Nota 2016-053. 26 blz.; 1 fig.; 21 tab.; 12 ref.

Valk, W.L. (2014). Brief d.d. 4 juli 2014 aan de Staatssecretaris van Economische Zaken, met bijlagen: Hoofdlijnen van voorstel voor vernieuwd pachtrecht; Lijst van deelnemers aan het overleg (Spelderholt I).

Valk, W.L., G.M.F. Snijders en H.A. Verbakel-van Bommel (2014). Het Akkoord van Spelderholt. Tijdschrift voor Agrarisch Recht, Nr. 9 september 2014.

Valk, W.L. (2015). Brief aan de Staatssecretaris van Economische Zaken d.d. 1 september 2015 (Spelderholt II). 


\section{Bijlage 1 Grondbeloning}

Tabel B1.1 Grondbeloning (euro/ha) na reservering, 5-jaarsgemiddelde

\begin{tabular}{lrrrrrrr} 
& $2003-2007$ & $2004-2008$ & $2005-2009$ & $2006-2010$ & $2007-2011$ & $2008-2012$ & $2009-2013$ \\
\hline Pachtnormjaar & 2009 & - & 2011 & 2012 & 2013 & 2014 & 2015 \\
\hline Bouwhoek en Hogeland & 604 & 594 & 634 & 791 & 703 & 671 & 793 \\
\hline Veenkoloniën en Oldambt & 385 & 417 & 392 & 477 & 580 & 639 & 765 \\
\hline Noordelijk weidegebied & 636 & 707 & 619 & 670 & 770 & 724 & 820 \\
\hline Oostelijk veehouderijgebied & 628 & 703 & 557 & 548 & 637 & 585 & 667 \\
\hline Centraal veehouderijgebied & 581 & 640 & 577 & 566 & 586 & 497 & 622 \\
\hline IJsselmeerpolders & 924 & 818 & 991 & 1207 & 873 & 1046 & 1304 \\
\hline Westelijk Holland & 339 & 392 & 360 & 468 & 513 & 602 & 695 \\
\hline Waterland en Droogmakerijen & 476 & 461 & 390 & 407 & 414 & 332 & 394 \\
\hline Hollands/Utrechts weidegebied & 502 & 537 & 493 & 612 & 802 & 787 & 910 \\
\hline Rivierengebied & 617 & 742 & 699 & 778 & 914 & 844 & 929 \\
\hline Zuidwestelijk akkerbouwgebied & 569 & 526 & 600 & 742 & 549 & 709 & 708 \\
\hline Zuidwest Brabant & 496 & 613 & 574 & 590 & 614 & 639 & 734 \\
\hline Zuidelijk veehouderijgebied & 708 & 764 & 617 & 604 & 746 & 717 & 791 \\
\hline Zuid-Limburg & 439 & 570 & 609 & 753 & 834 & 949 & 1039 \\
\hline Nederland & 597 & 636 & 586 & 654 & 691 & 697 & 794 \\
\hline Bron Wagn
\end{tabular}

Bron: Wageningen Economic Research.

Tabel B1.2 Verandering (\%) grondbeloning ten opzichte van voorgaande periode

\begin{tabular}{lrrrrrr} 
& $2004-2008$ & $2005-2009$ & $2006-2010$ & $2007-2011$ & $2008-2012$ & $2009-2013$ \\
\hline Bouwhoek en Hogeland & -2 & 7 & 25 & -11 & -5 & 18 \\
\hline Veenkoloniën en Oldambt & 8 & -6 & 22 & 22 & 10 & 20 \\
\hline Noordelijk weidegebied & 11 & -12 & 8 & 15 & -6 & 13 \\
\hline Oostelijk veehouderijgebied & 12 & -21 & -2 & 16 & -8 & 14 \\
\hline Centraal veehouderijgebied & 10 & -10 & -2 & 4 & -15 & 25 \\
\hline IJsselmeerpolders & -11 & 21 & 22 & -28 & 20 & 25 \\
\hline Westelijk Holland & 15 & -8 & 30 & 10 & 17 & 15 \\
\hline Waterland en Droogmakerijen & -3 & -15 & 4 & 2 & -20 & 19 \\
\hline Hollands/Utrechts weidegebied & 7 & -8 & 24 & 31 & -2 & 16 \\
\hline Rivierengebied & 20 & -6 & 11 & 17 & -8 & 10 \\
\hline Zuidwestelijk akkerbouwgebied & -7 & 14 & 24 & -26 & 29 & 0 \\
\hline Zuidwest Brabant & 24 & -6 & 3 & 4 & 4 & 15 \\
\hline Zuidelijk veehouderijgebied & 8 & -19 & -2 & 24 & -4 & 10 \\
\hline Zuid-Limburg & 30 & 7 & 24 & 11 & 14 & 9 \\
\hline Nederland & 7 & -8 & 12 & 6 & 1 & 14 \\
\hline
\end{tabular}

Bron: Wageningen Economic Research. 


\section{Bijlage 2 Pachtnormen}

Tabel B2.1 Pachtnormen (euro/ha), 2009, 2011-2015

\begin{tabular}{|c|c|c|c|c|c|c|}
\hline & 2009 & 2011 & 2012 & 2013 & 2014 & 2015 \\
\hline Bouwhoek en Hogeland & 599 & 697 & 712 & 633 & 604 & 714 \\
\hline Veenkoloniën en Oldambt & 421 & 431 & 477 & 522 & 575 & 689 \\
\hline Oostelijk veehouderijgebied & 635 & 613 & 548 & 573 & 527 & 634 \\
\hline Centraal veehouderijgebied & 646 & 635 & 623 & 527 & 497 & 622 \\
\hline Westelijk Holland & 404 & 396 & 515 & 462 & 542 & 660 \\
\hline Waterland en Droogmakerijen & 514 & 429 & 387 & 373 & 315 & 394 \\
\hline Hollands/Utrechts weidegebied & 533 & 542 & 582 & 722 & 708 & 819 \\
\hline Rivierengebied & 667 & 769 & 739 & 823 & 760 & 836 \\
\hline Zuid-Limburg & 539 & 670 & 715 & 751 & 854 & 935 \\
\hline Nederland & 537 & 645 & 654 & 622 & 627 & 715 \\
\hline
\end{tabular}

Bron: Wageningen Economic Research.

Tabel B2.2 Veranderpercentage pachtnormen (in \%), 2009, 2011-2015

\begin{tabular}{|c|c|c|c|c|c|c|}
\hline & 2009 & 2011 & 2012 & 2013 & 2014 & 2015 \\
\hline Veenkoloniën en Oldambt & 10 & 2 & 11 & 9 & 10 & 20 \\
\hline Oostelijk veehouderijgebied & 23 & -3 & -11 & 5 & -8 & 20 \\
\hline Centraal veehouderijgebied & 36 & -2 & -2 & -15 & -6 & 25 \\
\hline Westelijk Holland & -8 & -2 & 30 & -10 & 17 & 22 \\
\hline Waterland en Droogmakerijen & 23 & -17 & -10 & -4 & -16 & 25 \\
\hline Hollands/Utrechts weidegebied & 13 & 2 & 7 & 24 & -2 & 16 \\
\hline Rivierengebied & 43 & 15 & -4 & 11 & -8 & 10 \\
\hline Zuid-Limburg & -5 & 24 & 7 & 5 & 14 & 9 \\
\hline Nederland & & & 1 & -5 & 1 & 14 \\
\hline
\end{tabular}

Bron: Wageningen Economic Research. 


\section{Bijlage 3 Betaalde pachtprijzen}

Tabel B3.1 Pachtprijzen (euro/ha), 2007-2014

\begin{tabular}{lrrrrrrrr} 
& 2007 & 2008 & 2009 & 2010 & 2011 & 2012 & 2013 & 2014 a) \\
Bouwhoek en Hogeland & 453 & 481 & 543 & 516 & 547 & 619 & 648 & 644 \\
\hline Veenkoloniën en Oldambt & 307 & 318 & 342 & 353 & 368 & 420 & 453 & 528 \\
\hline Noordelijk weidegebied & 368 & 422 & 435 & 485 & 508 & 522 & 543 & 591 \\
\hline Oostelijk veehouderijgebied & 428 & 452 & 450 & 497 & 542 & 585 & 562 & 579 \\
\hline Centraal veehouderijgebied & 411 & 435 & 434 & 458 & 519 & 517 & 543 & 500 \\
\hline IJsselmeerpolders & 584 & 687 & 718 & 782 & 755 & 761 & 899 & 754 \\
\hline Westelijk Holland & 410 & 395 & 393 & 363 & 410 & 490 & 589 & 531 \\
\hline Waterland en Droogmakerijen & 328 & 348 & 372 & 388 & 419 & 378 & 363 & 407 \\
\hline Hollands/Utrechts weidegebied & 458 & 469 & 479 & 469 & 477 & 506 & 518 & 614 \\
\hline Rivierengebied & 416 & 428 & 448 & 565 & 582 & 603 & 625 & 607 \\
\hline Zuidwestelijk akkerbouwgebied & 435 & 495 & 527 & 543 & 544 & 593 & 679 & 568 \\
\hline Zuidwest-Brabant & 449 & 494 & 436 & 540 & 562 & 565 & 612 & 643 \\
\hline Zuidelijk veehouderijgebied & 506 & 478 & 485 & 532 & 576 & 576 & 547 & 534 \\
\hline Zuid-Limburg & 453 & 486 & 494 & 499 & 500 & 541 & 590 & 618 \\
\hline Nederland (gewogen) & 428 & 462 & 479 & 514 & 534 & 565 & 602 & 588 \\
\hline
\end{tabular}

a) Voorlopige cijfers.

Bron: Wageningen Economic Research.

Tabel B3.2 Prijsmutatie (\%) per jaar, 2008-2014

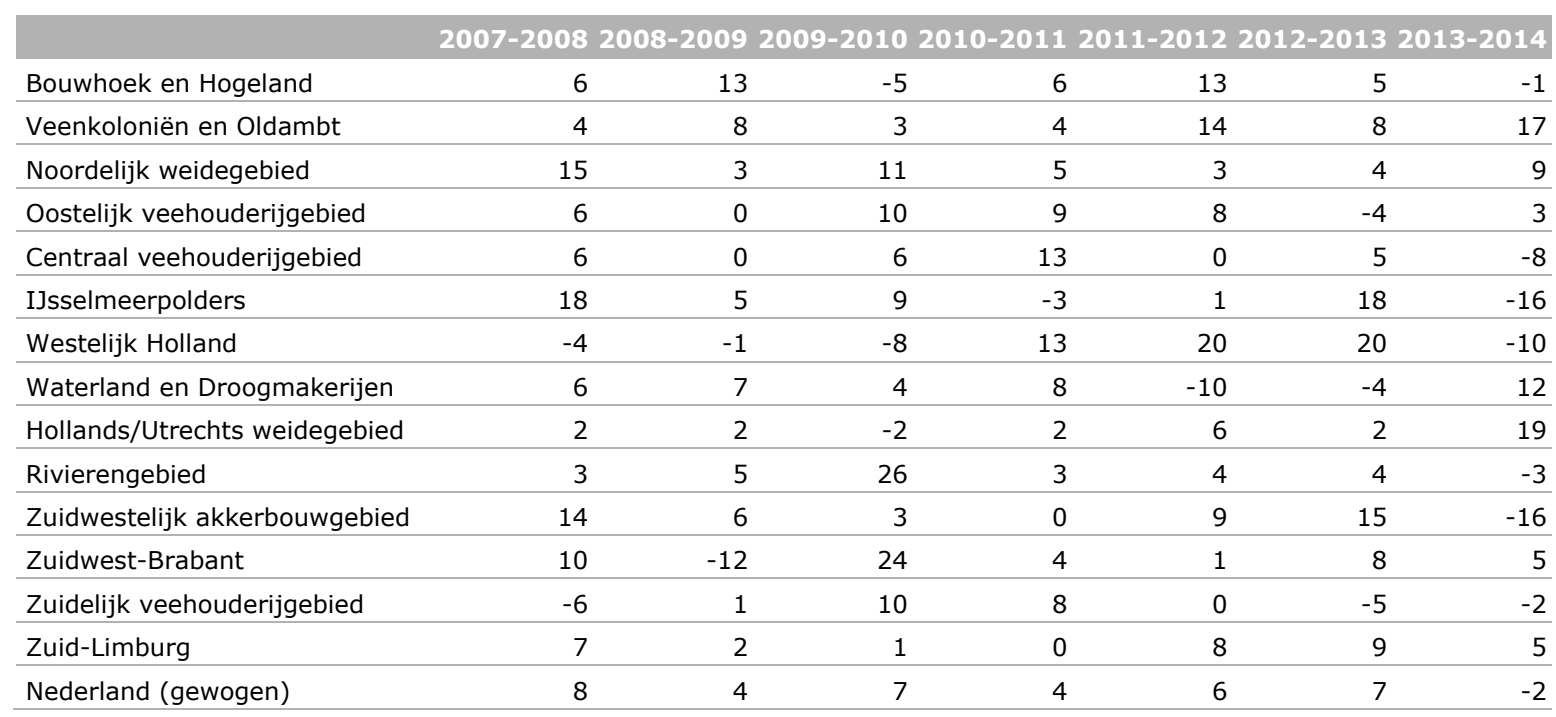

Bron: Wageningen Economic Research. 


\section{Bijlage 4 Grondbeloning, pachtnormen en betaalde pachtprijzen (euro/ha) per pachtprijsgebied}

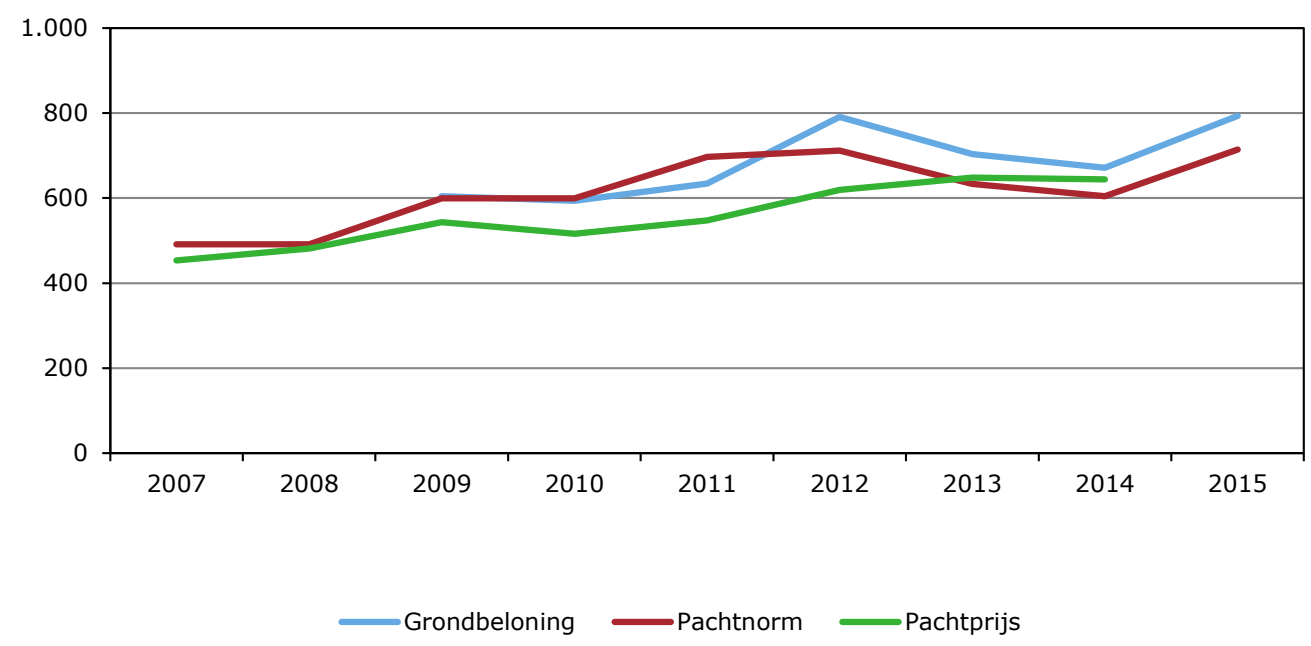

Figuur B4.1 Bouwhoek en Hogeland

Bron: Wageningen Economic Research.

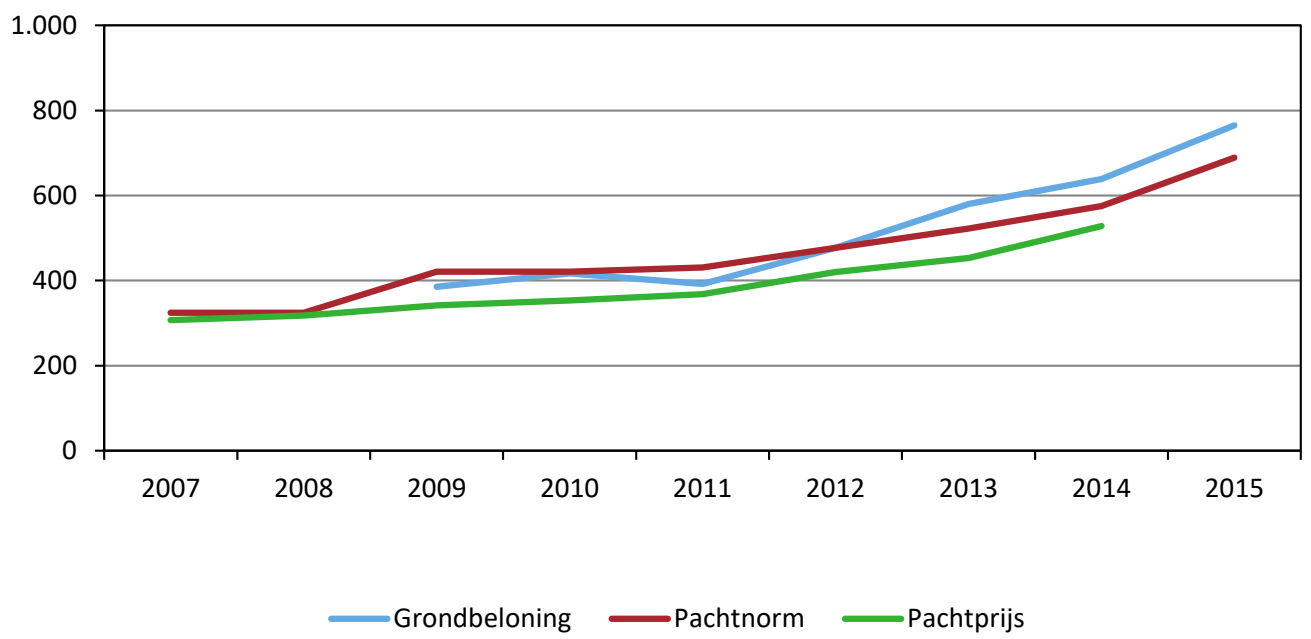

Figuur B4.2 Veenkoloniën en Oldambt

Bron: Wageningen Economic Research. 


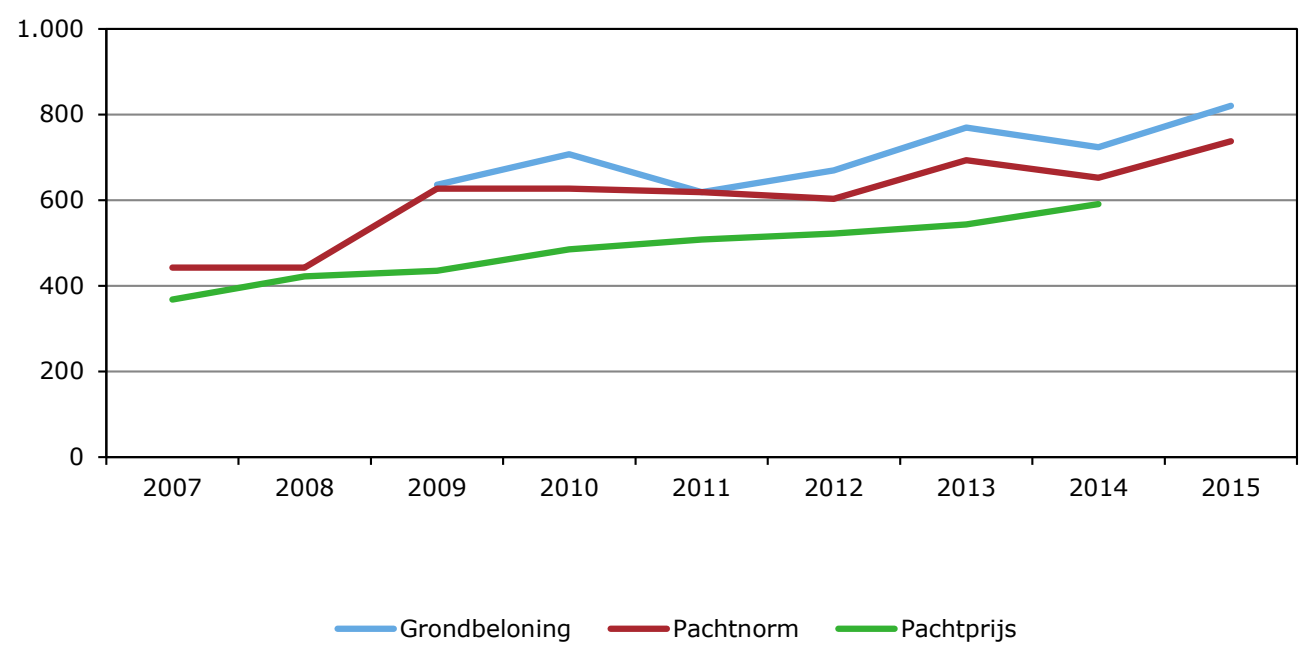

Figuur B4.3 Noordelijk weidegebied

Bron: Wageningen Economic Research.

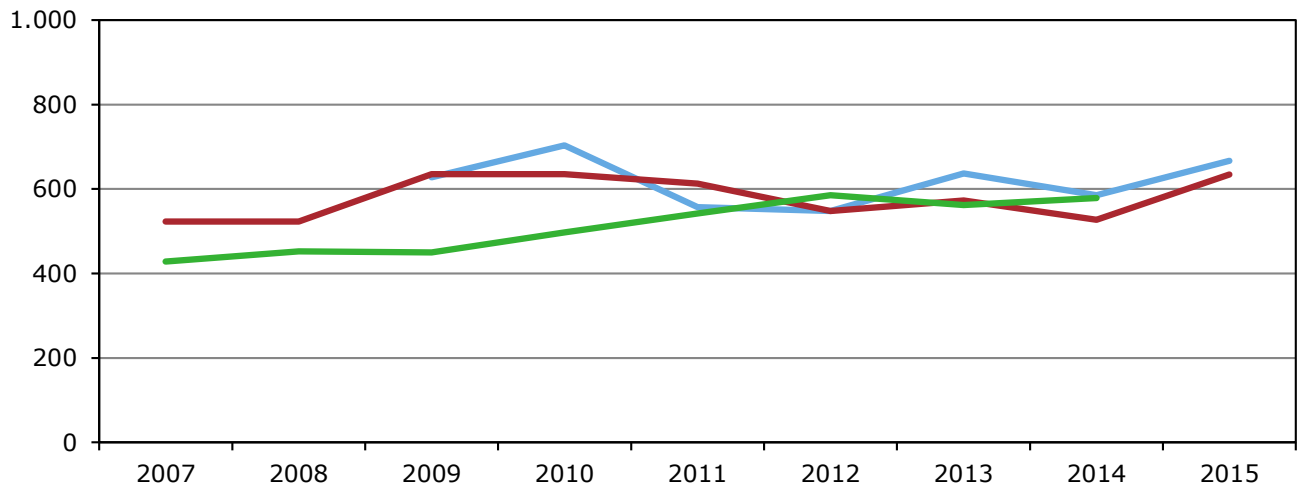

Grondbeloning $\longrightarrow$ Pachtnorm Pachtprijs

Figuur B4.4 Oostelijk veehouderijgebied

Bron: Wageningen Economic Research.

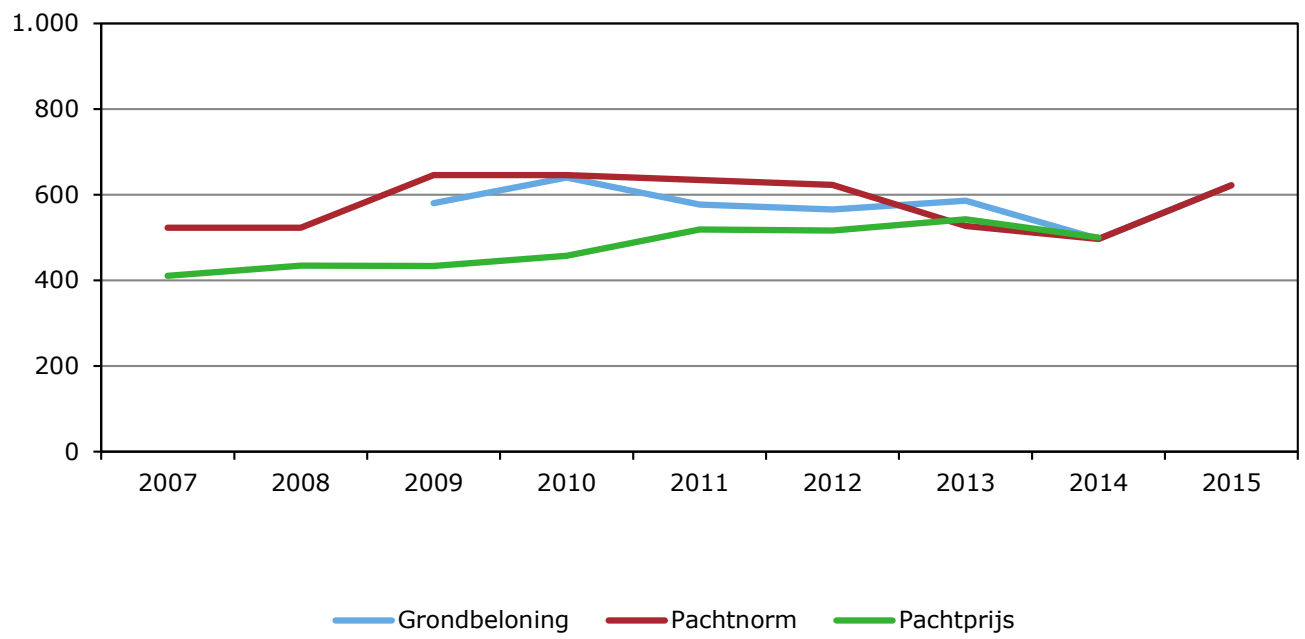

Figuur B4.5 Centraal veehouderijgebied

Bron: Wageningen Economic Research. 


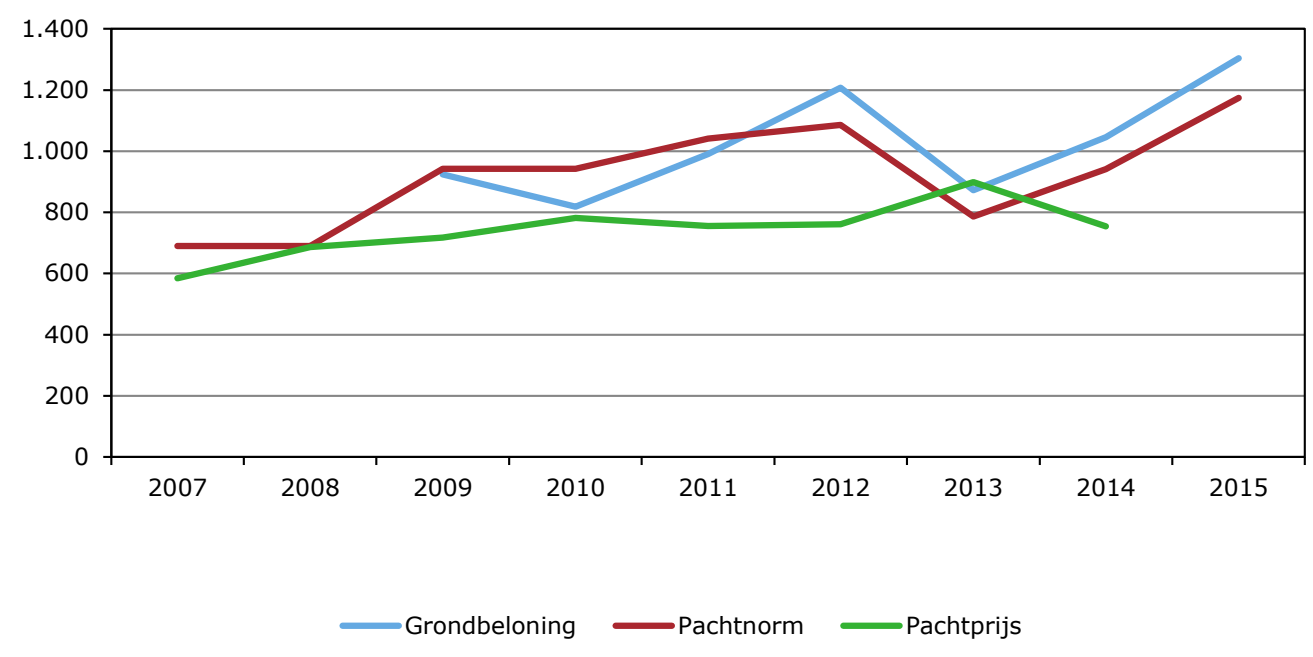

Figuur B4.6 IJsselmeerpolders

Bron: Wageningen Economic Research.

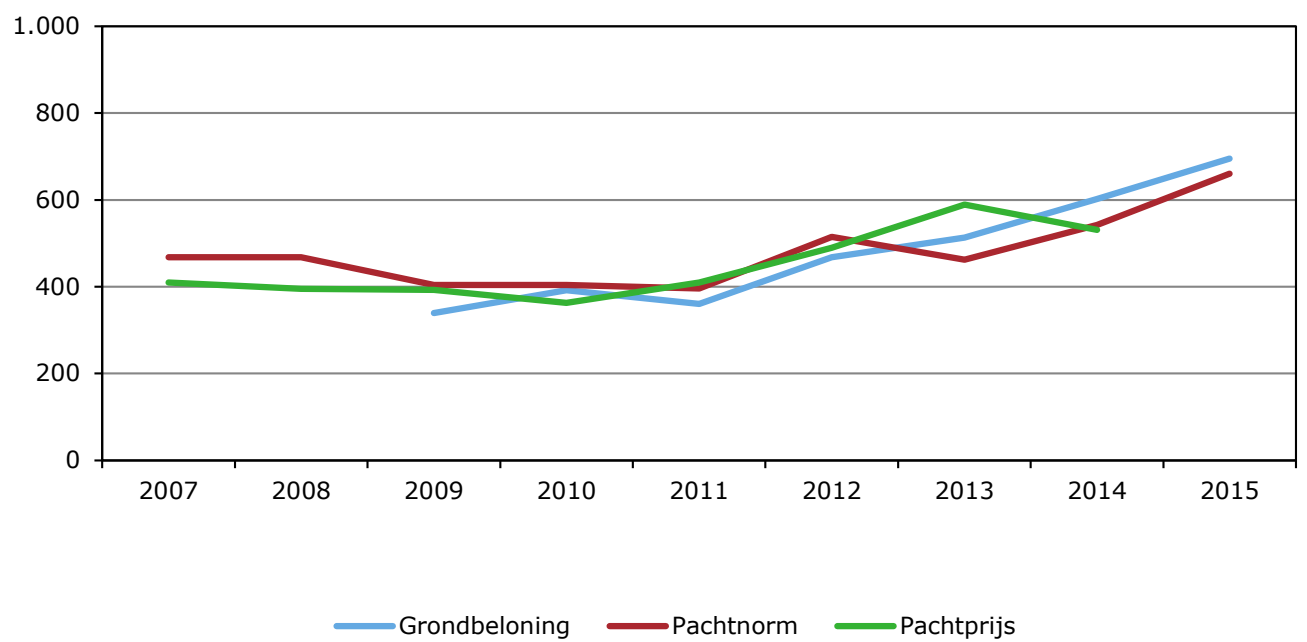

Figuur B4.7 Westelijk Holland

Bron: Wageningen Economic Research.

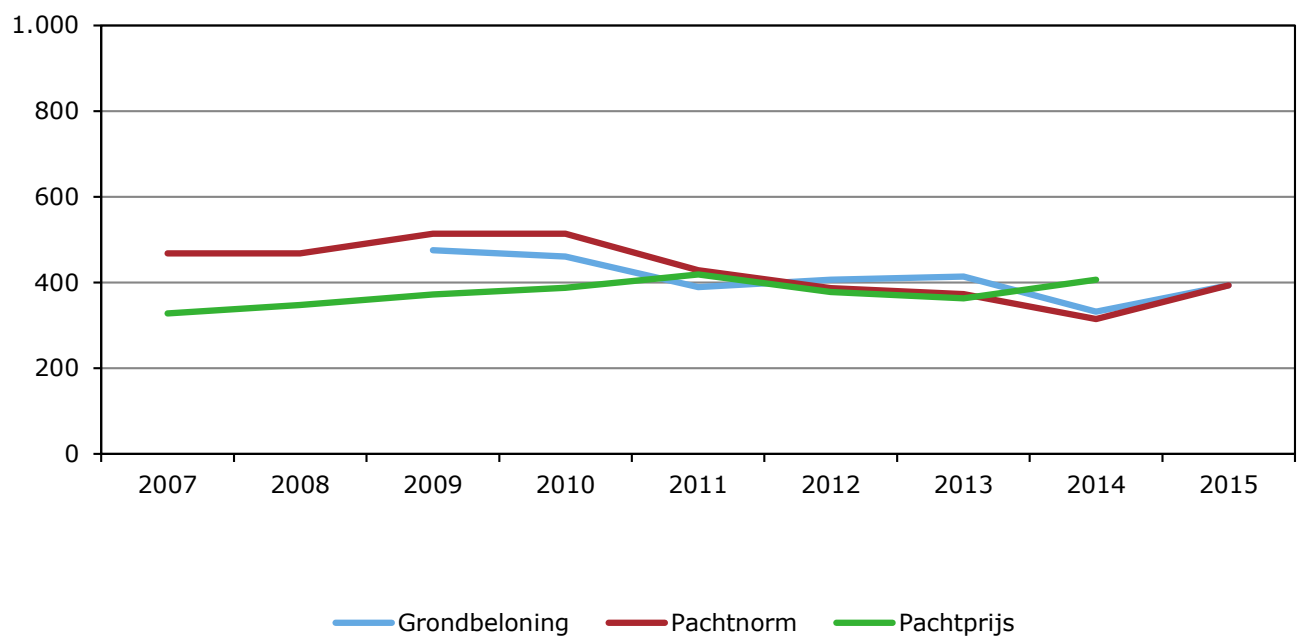

Figuur B4.8 Waterland en Droogmakerijen Bron: Wageningen Economic Research. 


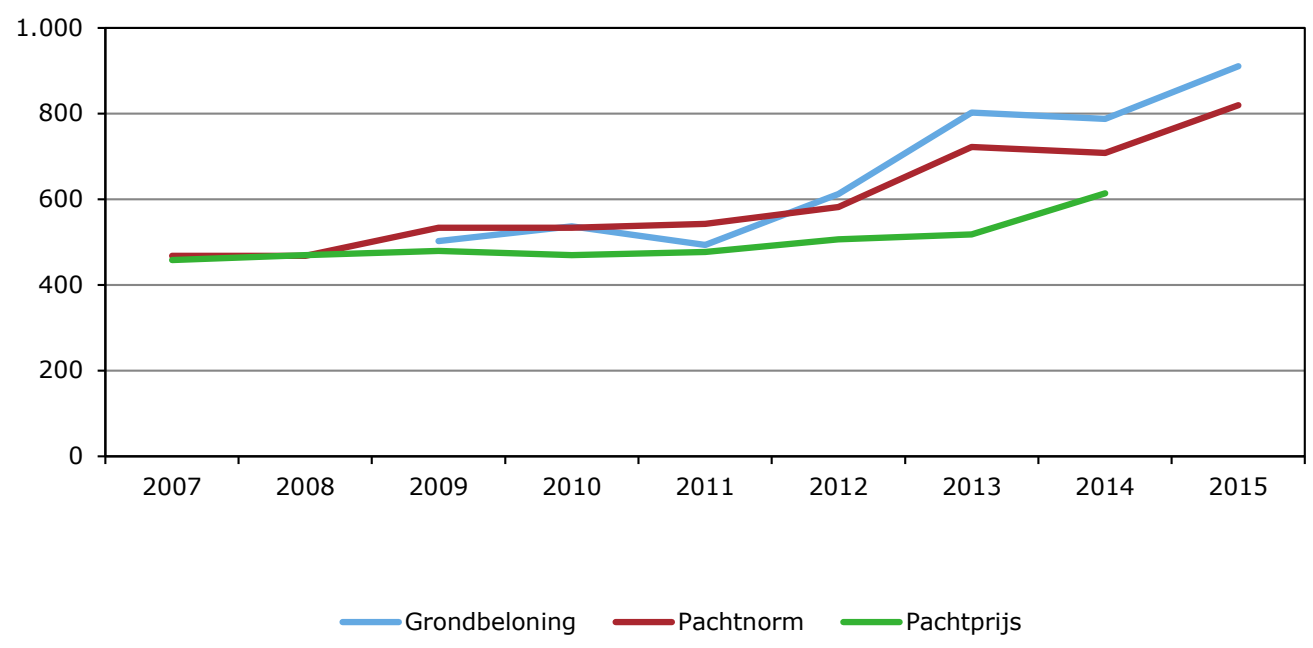

Figuur B4.9 Hollands/Utrechts weidegebied Bron: Wageningen Economic Research.

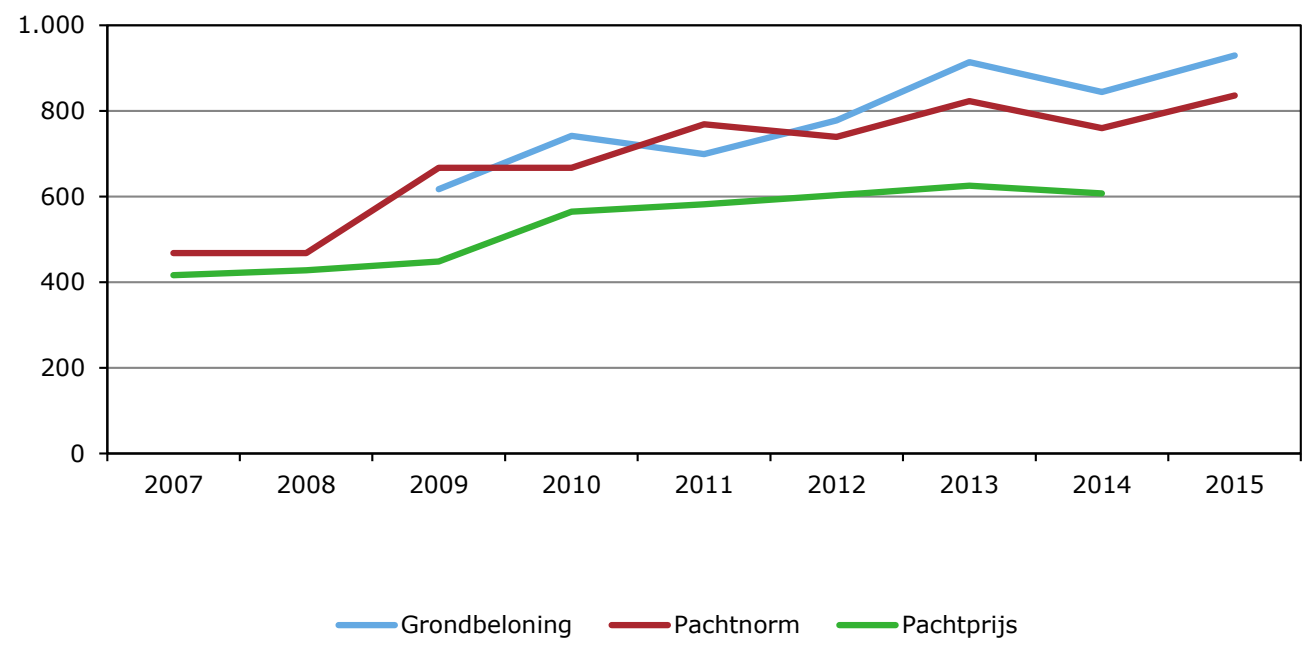

Figuur B4.10 Rivierengebied

Bron: Wageningen Economic Research.

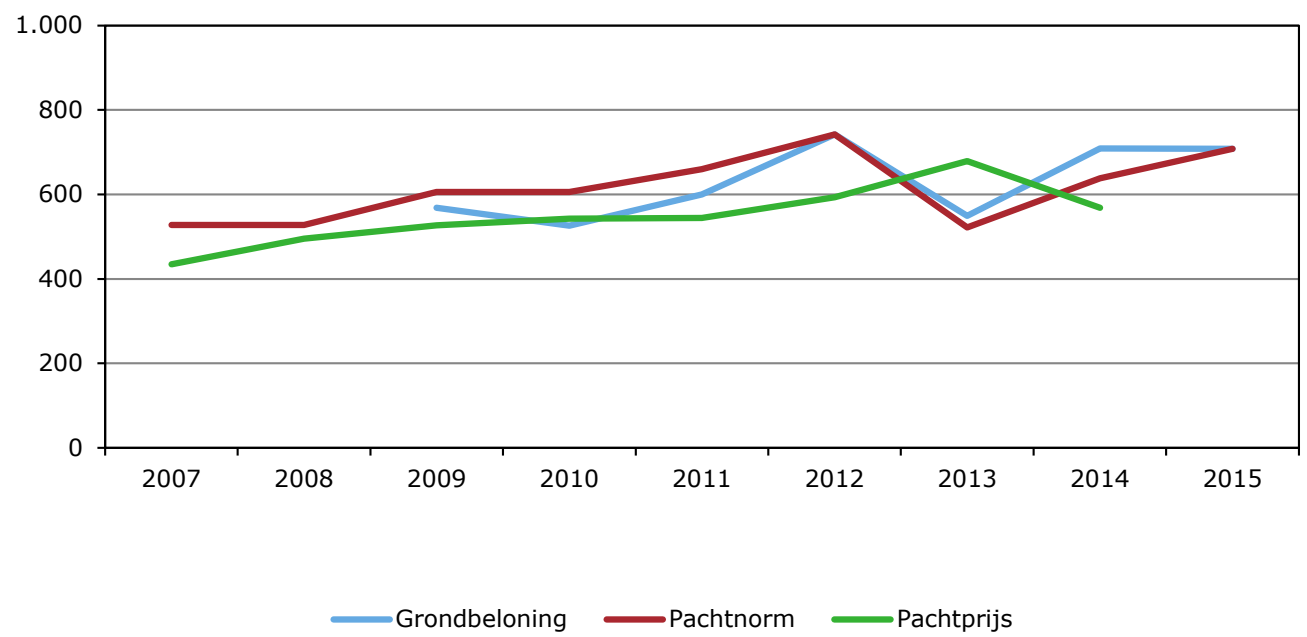

Figuur B4.11 Zuidwestelijk akkerbouwgebied Bron: Wageningen Economic Research. 


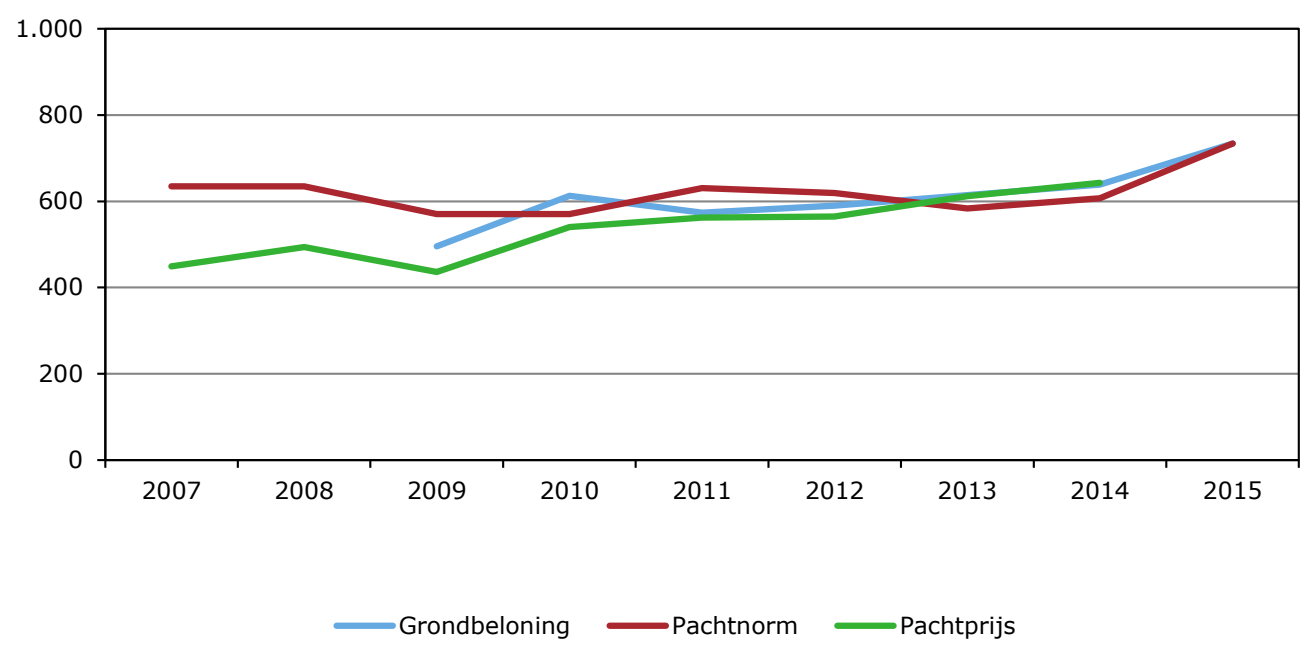

Figuur B4.12 Zuidwest-Brabant

Bron: Wageningen Economic Research.

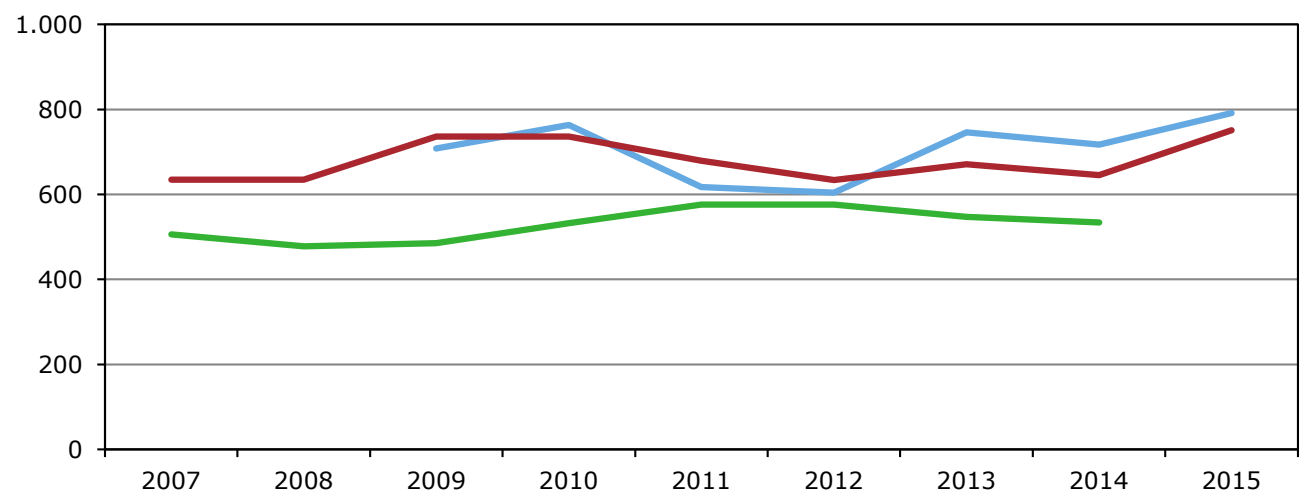

Grondbeloning Pachtnorm Pachtprijs

Figuur B4.13 Zuidelijk veehouderijgebied

Bron: Wageningen Economic Research.

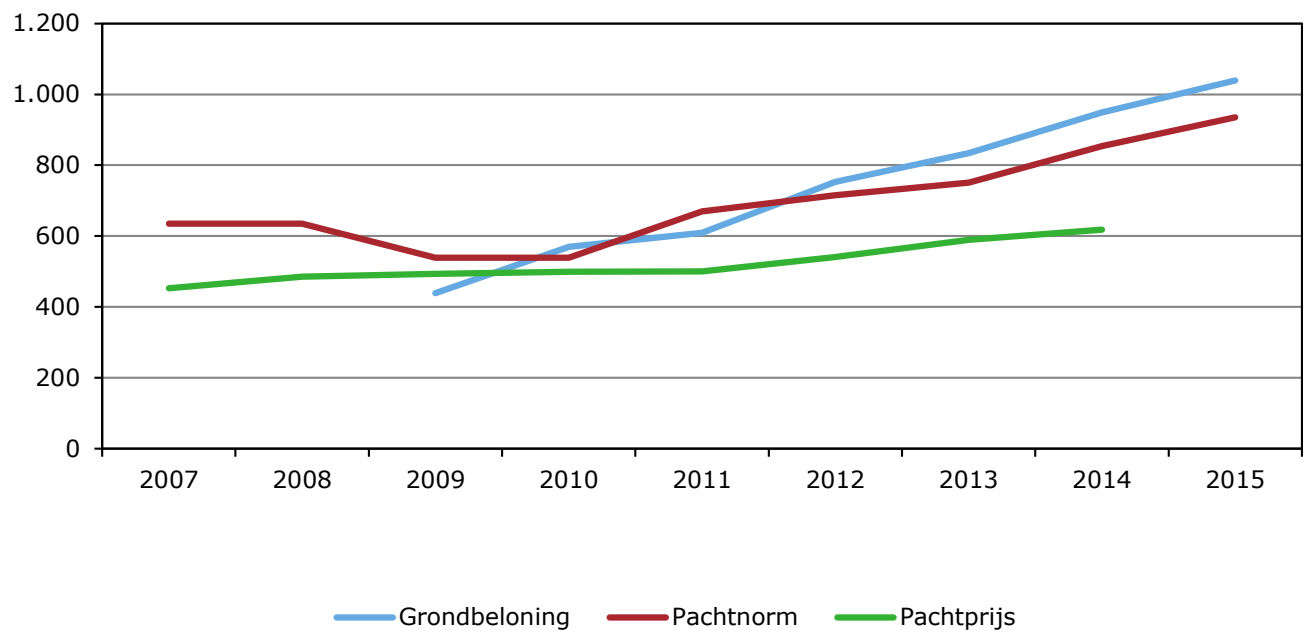

Figuur B4.14 Zuid-Limburg

Bron: Wageningen Economic Research. 
Wageningen Economic Research Postbus 29703

2502 LS Den Haag

T 0703358330

Ecommunications.ssg@wur.nl

www.wur.nl/economic-research

Wageningen Economic Research NOTA

2016-115
De missie van Wageningen University \& Research is 'To explore the potential of nature to improve the quality of life'. Binnen Wageningen University \& Research bundelen Wageningen University en gespecialiseerde onderzoeksinstituten van Stichting Wageningen Research hun krachten om bij te dragen aan de oplossing van belangrijke vragen in het domein van gezonde voeding en leefomgeving. Met ongeveer 30 vestigingen, 5.000 medewerkers en 10.000 studenten behoort Wageningen University \& Research wereldwijd tot de aansprekende kennisinstellingen binnen haar domein. De integrale benadering van de vraagstukken en de samenwerking tussen verschillende disciplines vormen het hart van de unieke Wageningen aanpak. 



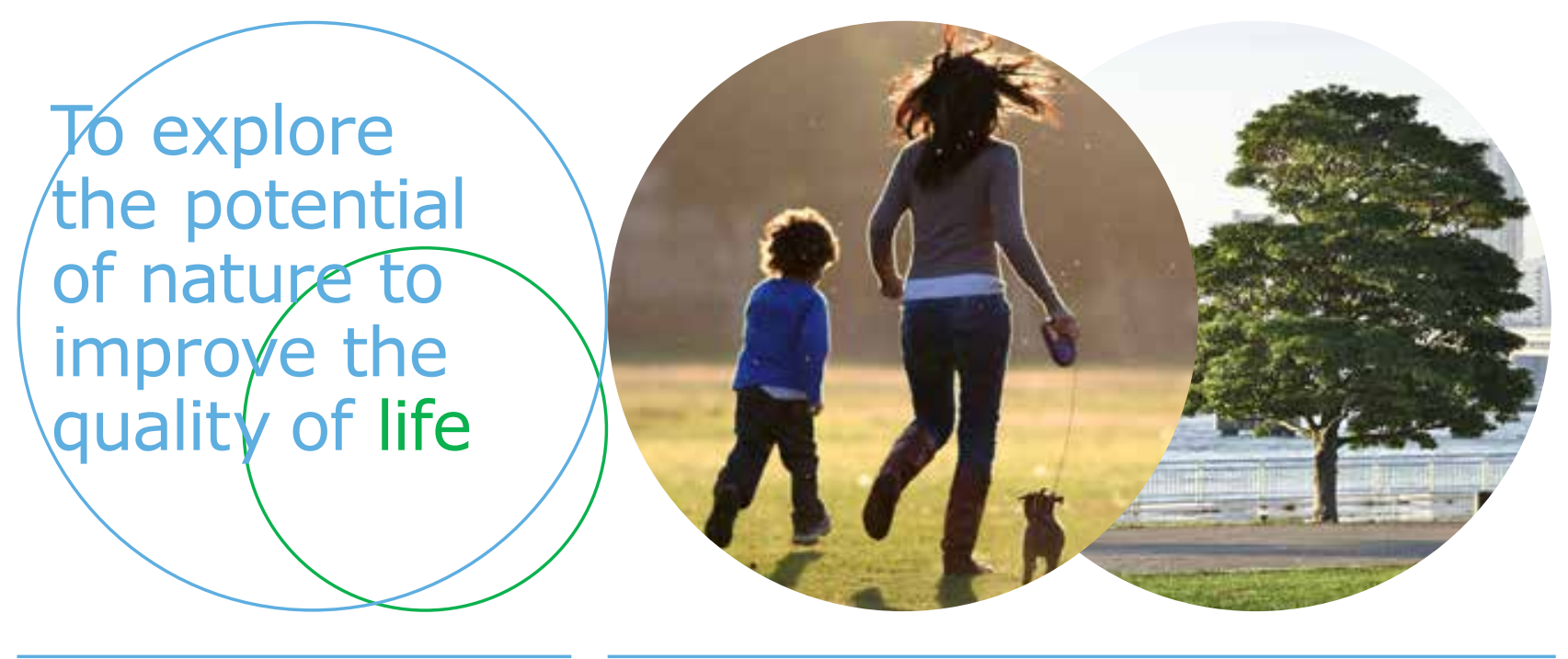

Wageningen Economic Research Postbus 29703

2502 LS Den Haag

E communications.ssg@wur.nl

$\mathrm{T}+31(0) 703358330$

www.wur.nl/economic-research

Nota $2016-115$
De missie van Wageningen University \& Research is 'To explore the potential of nature to improve the quality of life'. Binnen Wageningen University \& Research bundelen Wageningen University en gespecialiseerde onderzoeksinstituten van Stichting Wageningen Research hun krachten om bij te dragen aan de oplossing van belangrijke vragen in het domein van gezonde voeding en leefomgeving. Met ongeveer 30 vestigingen, 5.000 medewerkers en 10.000 studenten behoort Wageningen University \& Research wereldwijd tot de aansprekende kennisinstellingen binnen haar domein. De integrale benadering van de vraagstukken en de samenwerking tussen verschillende disciplines vormen het hart van de unieke Wageningen aanpak. 